\title{
Systematic Mutagenesis of All Predicted gntR Genes in Xanthomonas campestris pv. campestris Reveals a GntR Family Transcriptional Regulator Controlling Hypersensitive Response and Virulence
}

\author{
Shi-Qi An, Guang-Tao Lu, Hui-Zhao Su, Rui-Fang Li, Yong-Qiang He, Bo-Le Jiang, Dong-Jie Tang, and \\ Ji-Liang Tang \\ State Key Laboratory for Conservation and Utilization of Subtropical Agro-biosciences, The Key Laboratory of Ministry \\ of Education for Microbial and Plant Genetic Engineering, and College of Life Science and Technology, Guangxi University, \\ 100 Daxue Road, Nanning, Guangxi 530004, China
}

Submitted 4 August 2010. Accepted 24 April 2011.

The GntR family is one of the most abundant and widely distributed groups of helix-turn-helix transcriptional regulators in bacteria. Six open reading frames in the genome of the plant pathogen Xanthomonas campestris pv. campestris were predicted to encode GntR regulators. All six of the predicted GntR-encoding genes were individually mutagenized and mutants from five of them were successfully obtained. Plant disease response assays revealed that one, whose product belongs to the YtrA subfamily and has been named HpaR1, is involved in the hypersensitive response (HR) and virulence. Electrophoretic mobility shift assays and in vitro transcription assays revealed that HpaR1 could repress its own transcription level through binding to its promoter sequence, indicating an autoregulatory feedback inhibition mechanism for HpaR1 expression. Promoter-gusA reporter and reverse-transcription polymerase chain reaction analyses revealed that $H$ paR1 positively and negatively affects the expression of HR and pathogenicity (hrp) genes in host plant and standard media, respectively. Constitutive expression of the key hrp regulator, $h r p G$, in the $h p a R 1$ mutant could bypass the requirement of HpaR1 for the induction of wild-type HR, suggesting that HpaR1 regulates the expression of $h r p$ genes that encode the type III secretion system via $h r p G$.

Bacteria, like other living organisms, can accurately modify their gene expression to complete their life cycle and meet the challenge of microenvironmental changes. One common mechanism is to control the level of gene transcription via transcriptional regulator proteins. A large number of transcriptional regulators in bacteria have been identified and categorized into several groups according to their mode of DNA binding and particular conserved motifs (Pabo and Sauer 1992). Among those, the most common is the helix-turn-helix (HTH) group, whose conserved DNA recognition motif consists of an $\alpha$-helix, a turn, and a second $\alpha$-helix (Haydon and

\section{S.-Q. An and G.-T. Lu contributed equally to this work.}

Corresponding author: J.-L. Tang; Telephone: +86-771-3239566; Fax: +86-771-3239413; E-mail: jltang@gxu.edu.cn

* The $\boldsymbol{e}$-Xtra logo stands for "electronic extra" and indicates one supplementary figure and one supplementary table are published online.
Guest 1991). Within the HTH group, the transcriptional regulators have been divided into different families based on sequence similarities in the DNA-binding domains (Pabo and Sauer 1992). The GntR family is one of the most abundant and widely distributed HTH families. More than 8,500 GntR family members have been annotated in diverse bacterial genomes and the number of GntR regulators varies from one bacterial species to another (Hoskisson and Rigali 2009). Many important GntR family members regulating various cellular processes have been identified and characterized (Hoskisson and Rigali 2009; Rigali et al. 2002); however, the function of the most predicted GntR members in various bacteria is unknown. Furthermore, a large repertoire of characterized GntR regulators is associated with diverse metabolic pathways and, thus far, only two pieces of evidence indicate that GntR members can regulate virulence in pathogenic bacteria. One is in Brucella melitensis, a gram-negative coccobacillus bacterium that causes the brucellosis disease affecting sheep, cattle, and sometimes humans (Haine et al. 2005); the other is in Mycobacterium tuberculosis, the etiologic agent of tuberculosis in humans (Casali et al. 2006).

The gram-negative bacterium Xanthomonas campestris pv. campestris is the causal agent of black rot disease of cruciferous crops. This pathogen has been used as a model bacterium for studying the molecular mechanisms of pathogen-plant interactions. $X$. campestris pv. campestris can infect almost all members of the crucifer family (Brassicaceae), including important vegetables such as broccoli, brussels sprouts, cabbage, cauliflower, kale, mustard, and radish; the major oil crop rape; as well as the model plant Arabidopsis thaliana (Alvarez 2000). The black rot caused by $X$. campestris pv. campestris is a typical vascular disease. $X$. campestris pv. campestris infects host plants via wounds or hydathodes, which are specialized pores on the leaf margins of higher plants and connect to the vascular system. After infection, the bacterial cells multiply in vascular tissues, leading to the development of typical symptoms: vein blackening and $\mathrm{V}$-shaped chlorotic and necrotic lesions extending from leaf margins along veins. It is clear that for successful invasion and proliferation during the pathogenesis of $X$. campestris pv. campestris, the bacterial cells must overcome the multilayered plant defense response and acquire nutrients from infected plant tissues. Over the past several decades, a large number of genes essential for the pathogenesis of $X$. campestris pv. campestris have been identified, and 
the virulence regulation in $X$. campestris pv. campestris has been studied in some detail (Dow 2008; Huang et al. 2009; Mole et al. 2007). The entire genome sequences of three $X$. campestris pv. campestris strains have been determined, and six GntR regulator-encoding genes were predicted in each of the genomes (da Silva et al. 2002; Qian et al. 2005; Vorhölter et al. 2008).

The focus of this research was to address the issue of whether any of the predicted GntR family regulators plays a role in the pathogenicity of $X$. campestris pv. campestris. All six of the predicted GntR regulator-encoding genes in $X$. campestris pv. campestris 8004 were individually mutagenized and mutants derived from five of them were successfully obtained. Pathogenesis assays using a plant host revealed that one of them, the open reading frame (ORF) $X C_{-} 2736$, is essential for the hypersensitive response (HR) and virulence of $X$. campestris pv. campestris. HR is a visible disease resistance phenomenon with a type of rapid, localized, and programmed cell death in the pathogen-infection tissues of resistant host or nonhost plants (Alfano and Collmer 2004; Jones and Dangl 2006). A number of genes associated with $\mathrm{HR}$ and pathogenicity ( $h r p$ ) in plant-pathogenic bacteria have been identified. Most of the hrp genes encode components of the type III secretion system (T3SS), which is highly conserved among gram-negative pathogenic bacteria. The main function of the T3SS is to translocate bacterial effector proteins into host cells, and this system has been demonstrated to be one of the most important pathogenicity systems for both animal- and plant-pathogenic bacteria (Alfano and Collmer 2004; Cornelis and Van Gijsegem 2000; Hueck 1998; Lindgren 1997). In X. campestris pv. campestris, the $h r p$ genes are mainly composed of $h r p A$ to $h r p F$, six clustered operons that harbor more than 20 different genes. In addition, there are two key $h r p$ regulators, $h r p G$ and $h r p X$, whose loci are far away from the hrp cluster on the chromosome. HrpG and HrpX are a response regulator of two-component signal transduction systems and an AraC-family transcriptional activator of the HTH group, respectively. HrpG and HrpX form a regulatory cascade, in which HrpG regulates the expression of $h r p X$ and HrpX then activates the expression of $h r p A$ to $h r p F$ operons (Arlat et al. 1991; Huang et al. 2009). Here, in addition to the identification of the HR- and virulencerelated GntR regulator, we also present evidence to demonstrate that the GntR regulator controls the expression of the hrp genes via the key hrp regulator HrpG.

\section{RESULTS}

\section{Six predicted GntR regulators belong to three different subfamilies.}

As described above, the genomes of three $X$. campestris pv. campestris strains (American Type Culture Collection [ATCC] 33913, 8004, and B100) have been sequenced. Six ORF in each of the strains were predicted to encode GntR family transcriptional regulators based on their $\mathrm{N}$-terminal amino acid sequences, which display significant homology to the conserved N-terminal DNA-binding domain of the GntR family members (da Silva et al. 2002; Qian et al. 2005; Vorhölter et al. 2008). In this work, we used strain 8004 as a representative of $X$. campestris pv. campestris. The six GntR-encoding ORF in this strain were named $X C_{-} 0580, X C_{-} 0750, X C_{-} 2652$, $X C \_2736, X C \_3428$, and $X C \_3561$ (Fig. 1A) (Qian et al. 2005). Currently, the GntR family members are classified into seven subfamilies (AraR, DevA, FadR, HutC, MocR, PlmA, and $\mathrm{YtrA}$ ) based on the secondary structural features in their C-terminal domains (Hoskission and Rigali 2009; Rigali et al. 2002). To find out which subfamily the predicted $X$. campestris pv. campestris GntR proteins belong to, we constructed an unrooted, phylogenetic tree with representatives of previously classified GntR subfamily members as reference proteins (Vindal et al. 2007). The unrooted tree showed that one (XC_2736), two (XC_0580 and XC_3428), and three (XC_0750, XC_2652, and XC_3561) X. campestris pv. campestris GntR proteins belong to YtrA, FadR, and HutC subfamilies, respectively (Fig. 1B).

\section{Mutagenesis of the predicted gntR genes.}

First, we screened a mutant library of the $X$. campestris pv. campestris 8004, which was constructed by transposon Tn5gusA5 insertion mutagenesis and composed of mutants derived from approximately 2,500 ORF in our laboratory, for mutants of the predicted GntR regulator-coding genes. Two Tn5gusA5 insertion mutants for the ORF XC_3428, named 011B06 and 208B02 (Table 1), were found in the mutant library, and none for other gntR-coding genes was obtained. To mutate the other five GntR-coding genes, the homologous suicide plasmid integration method described by Windgassen and associates (2000) was employed (details below), and mutants with polar or nonpolar effects for the ORF $X C_{-} 0750$, $X C \_2652, X C \_2736$, and $X C_{-} 3561$ were successfully obtained and named 0750pk, 2652nk, 2736nk, and 3561pk, respectively (Table 1). To determine whether a mutation in these genes had any effect on bacterial growth, the growth rates of the mutants and the wild-type 8004 were compared during growth in nutrient-rich complex medium NYG and minimal medium MMX (Daniels et al. 1984a). The results showed that all the mutants grew in a fashion similar to the wild-type strain in both media (data not shown), suggesting that a mutation in these GntRcoding genes does not affect $X$. campestris pv. campestris growth in standard media.

\section{One of the GntR members is involved in virulence and the HR.}

To investigate whether any of the predicted gnt $R$ genes are involved in the pathogenesis of $X$. campestris pv. campestris, the virulence of the mutants constructed above was tested on the host plant Chinese radish using the leaf-clipping method (details below). Ten days after inoculation, the XC_2736 mutant strain 2736 nk could only induce very weak disease symptoms on the inoculated leaves (Fig. 2A), while the other five mutant strains $(0750 \mathrm{pk}, 2652 \mathrm{nk}, 3561 \mathrm{pk}, 011 \mathrm{~B} 06$, and 208B02) induced wild-type disease symptoms with a mean lesion length of approximately $16 \mathrm{~mm}$ (data not shown). To study whether the attenuated virulence of the $X C \_2736$ mutant could be restored by the wild-type $X C \_2736$ gene in trans, a complemented strain, named C2736 (Table 1), was constructed (details below). Subsequently, the virulence of the complemented strain C2736 was compared with that of the wild-type strain. The result showed that the complemented strain provoked disease symptoms with a mean lesion length of $12.5 \mathrm{~mm}(78 \%$ of the wild type) (Fig. 2A), which is significantly longer than that caused by the mutant but significantly shorter than the wild type ( $P=0.01$ by $t$ test). This reveals that the virulence of the mutant could not be completely restored to the wild-type level by $X C \_2736$ cloned in pLAFR3. The vector pLAFR3 has been widely used for molecular studies in xanthomonads; however, its stability in cells might vary in different strains or be influenced by a cloned gene with extraordinary functions. To gain insight into the cause of the partial virulence restoration by $X C \_2736$ in trans, the stability of the recombinant plasmid pL2736 in the complemented strain C2736 in planta was assessed (details below). The result showed that only 80, 78.6, and $77.4 \%$ of the rifampicin (Rif)- and kanamycin (Kan)-resistant colonies from the infected leaves at 2, 4, and 6 days, respectively, after inoculation could grow on the tetracycline 
(Tet)-containing plates, suggesting that the recombinant plasmid pL2736 in the complemented strain is relatively unstable and that 20 to $22.6 \%$ of bacterial cells lost the plasmid pL2736 and reverted to mutant status in planta. This may explain why only $78 \%$ virulence of the mutant could be restored by $X C \_2736$ cloned in pLAFR3. To determine whether mutation in $X C \_2736$ results in a decrease in the proliferation of $X$. campestris pv. campestris in the host, the bacterial cell numbers of the mutant and the wild type in infected radish leaves were calculated and compared. The results showed that the bacterial CFU of the mutant recovered from the infected leaves was approximately six- to tenfold fewer than that of the wildtype strain 5 days postinoculation (Fig. 2B). These data reveal that XC_2736 is required for full virulence and growth of $X$. campestris pv. campestris in host plants.

The six gntR mutants obtained in this study $(0750 \mathrm{pk}, 2652 \mathrm{nk}$, $3561 \mathrm{pk}, 2736 \mathrm{nk}, 011 \mathrm{~B} 06$, and 208B02) were also examined for their ability to elicit the HR in nonhost plants. The examination was carried out by infiltrating bacterial suspensions with a cell concentration of $1 \times 10^{7} \mathrm{CFU} / \mathrm{ml}$ into the leaves of the pepper cultivar ECW-10R, a nonhost plant typically used to test the HR of $X$. campestris pv. campestris (Castañeda et al. 2005; Newman et al. 2001). The result was similar to that of the virulence test (i.e., apart from the $X C_{-} 2736$ mutant, no other mutant showed a significant difference on HR induction compared with the wild-type strain) (data not shown). The $X C \_2736$ mutant strain elicited a delayed and weakened HR, and this reduced HR could be restored to the wild-type level by $X C \_2736$ in trans (Fig. 2C). These results were substantiated using an electrolyte leakage assay. The $X C \_2736$ mutant strain 2736 nk exhibited significantly decreased electrolyte leakages at 8 and $16 \mathrm{~h}$ after inoculation compared with the wildtype strain (Fig. 2D). Overall, these plant tests have demonstrated that the ORF $X C_{\_} 2736$ is involved in the hrp of $X$. campestris pv. campestris. Therefore, we named XC_2736 $h r p$-associated regulator (hpaR) 1 .

\section{hpaRI and the genes $X C \_2737-2741$ \\ are transcribed as an operon.}

A survey of the genome sequence of $X$. campestris pv. campestris 8004 revealed that the HpaR1-encoding ORF $X C \_2736$ probably shares an operon with the ORF $X C_{\_} 2737$ to $X C_{-} 2741$ (Qian et al. 2005). These ORF are located in the genome sequence between positions 3287805 and 3291938
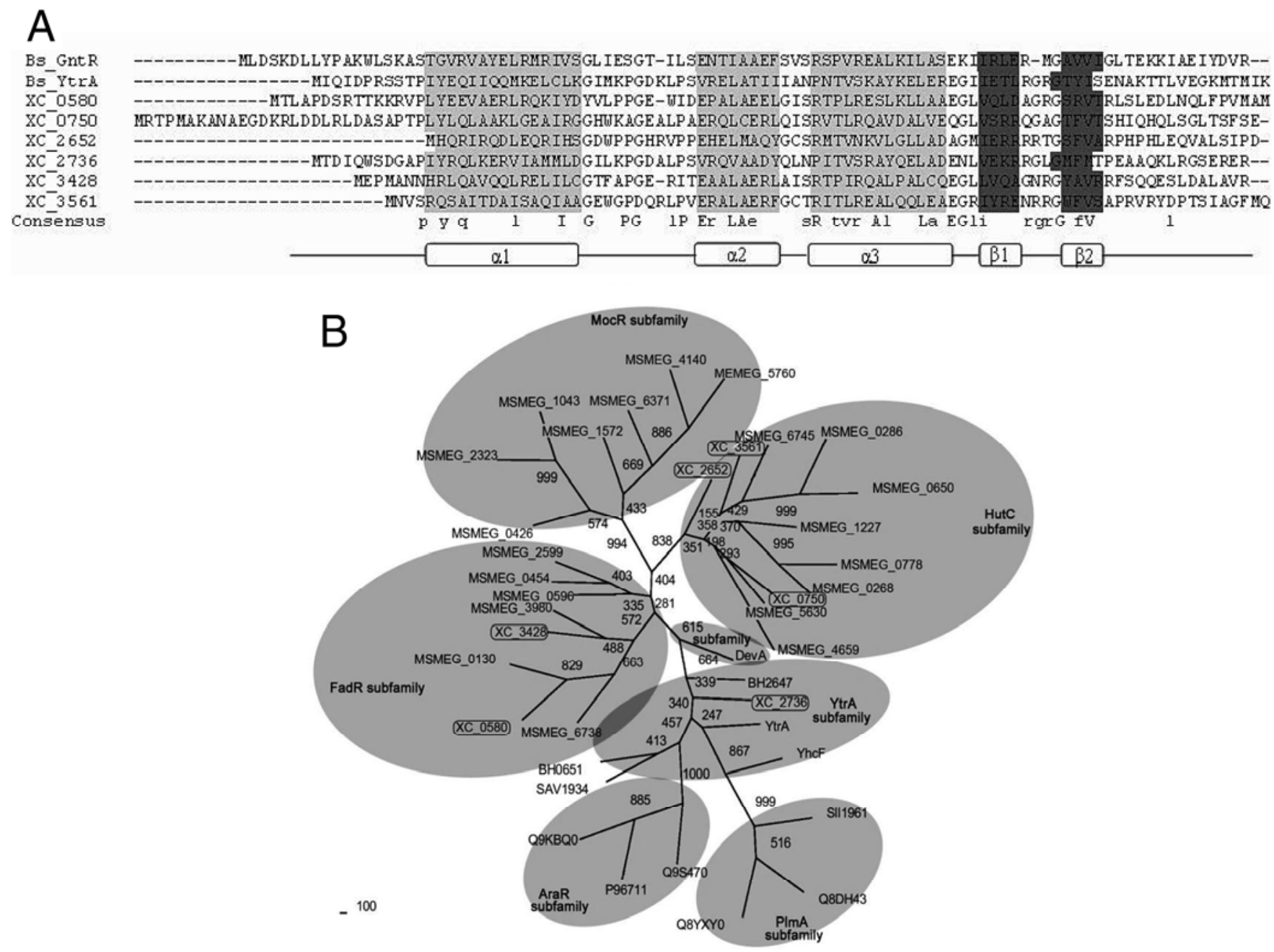

Fig. 1. In silico analysis of GntR family transcriptional regulator in Xanthomonas campestris pv. campestris. A, Structure-based sequence alignment of the N-terminal DNA-binding domain of proteins of the predicted X. campestris pv. campestris GntR members and the Bacillus subtilis GntR (Bs_GntR) (P10585) (Fujita et al. 1986) and YtrA (O34712) (Yoshida et al. 2000). High and low consensus levels were arbitrarily fixed at 75 and 50\% of identity, respectively, and are represented by the upper- and lowercase letters. In graphical representations, $\alpha$-helix region and $\beta$-sheet regions are highlighted with light- and dark-gray backgrounds. B, Unrooted tree of the proteins of predicted X. campestris pv. campestris GntR members, including representatives of all subfamily members (Hoskisson and Rigali 2009; Vindal et al. 2007) identified from different bacteria with 1,000 bootstrap replicates. Six predicted $X$. campestris pv. campestris GntR members belong to YtrA (XC_2736), FadR (XC_0580 and XC_3428), and HutC (XC_0750, XC_2652, and XC_3561) subfamilies. 
(Supplementary Fig. S1A) and have not been characterized. Apart from the ORF XC_2737 (YP_243806), which was annotated to encode an ABC transporter ATP-binding protein, the others (i.e., XC_2738-2741 [YP_243807, YP_243808, YP_243809, and YP_243810]) were predicted to encode conserved hypothetical proteins (Qian et al. 2005). As described above, HpaR1 belongs to the YtrA subfamily of GntR regulators. The location of its coding ORF in the genome is consis- tent with the observation that YtrA subfamily members often appear to be associated with ATP-binding cassette (ABC) transporters (Hoskission and Rigali 2009). To verify whether the ORF $X C \_2736$ to $X C \_2741$ are cotranscribed, the transcriptional products spanning two adjacent ORF were analyzed in the wild-type strain 8004 by reverse-transcription polymerase chain reaction (RT-PCR) (details below) using the corresponding oligonucleotides as primers (Supplementary Ta-

Table 1. Bacterial strains and plasmids used in this work

\begin{tabular}{|c|c|c|}
\hline Strains or plasmids & Relevant characteristics $^{\text {a }}$ & Reference or source \\
\hline \multicolumn{3}{|l|}{ Escherichia coli } \\
\hline JM109 & $\begin{array}{l}\text { RecA1, endA1, gyrA96, thi, supE44, relA1 } \Delta(\text { lac-proAB }) / \mathrm{F}^{\prime}\left[\text { traD36, lacI }{ }^{\mathrm{q}} \text {, }\right. \\
\quad \text { lacZ } \Delta \mathrm{M} 15]\end{array}$ & Yanisch-Perron et al. 1985 \\
\hline DH5 $\alpha$ & Ф00lacZM15 recA1 endA1 deoR & Gibco BRL, Life Technologies \\
\hline \multicolumn{3}{|c|}{ Xanthomonas campestris pv. campestris } \\
\hline 8004 & Wild type, Rif ${ }^{\mathrm{r}}$ & Daniels et al. 1984b \\
\hline $2736 n k$ & As 8004 , but $X C \_2736:: p K 18 m o b$, nonpolar effect. Rif $^{\mathrm{r}}$, $\mathrm{Kan}^{\mathrm{r}}$ & This work \\
\hline $2736 \mathrm{pk}$ & As 8004 , but $X C \_2736:: \mathrm{pK} 18 m o b$, polar effect. Rif $^{\mathrm{r}}$, Kan ${ }^{\mathrm{r}}$ & \\
\hline $011 \mathrm{~B} 06$ & As 8004 , but $X C \_3428:: T n 5$ gusA5, Rif $^{\mathrm{r}}, \mathrm{Kan}^{\mathrm{r}}$ & Laboratory collection \\
\hline 208B02 & As 8004 , but $X C \_3428:: T n 5$ gusA5, Rif $^{\mathrm{r}}, \mathrm{Kan}^{\mathrm{r}}$ & Laboratory collection \\
\hline 0750pk & As 8004 , but $X C \_0750:: \mathrm{pK} 18 m o b, \operatorname{Rif}^{\mathrm{r}}, \mathrm{Kan}^{\mathrm{r}}$ & This work \\
\hline $2652 \mathrm{nk}$ & As 8004 , but $X C \_2652:: \mathrm{pK} 18 m o b, \operatorname{Rif}^{\mathrm{r}}, \mathrm{Kan}^{\mathrm{r}}$ & This work \\
\hline $3561 \mathrm{pk}$ & As 8004 , but $X C \_3561:: \mathrm{pK} 18 m o b, \operatorname{Rif}^{\mathrm{r}}, \mathrm{Kan}^{\mathrm{r}}$ & This work \\
\hline $\mathrm{C} 2736$ & 2736nk harboring pL2736, $\operatorname{Rif}^{\mathrm{r}}, \mathrm{Kan}^{\mathrm{r}}, \mathrm{Tet}^{\mathrm{r}}$ & This work \\
\hline $8004 \mathrm{G}$ & $8004 \Delta h r p G ; \operatorname{Rif}^{\mathrm{r}}, \operatorname{Kan}^{\mathrm{r}}$ & Laboratory collection \\
\hline $8004 X$ & $8004 \Delta h r p X ; \operatorname{Rif}^{\mathrm{r}}, \mathrm{Kan}^{\mathrm{r}}$ & Laboratory collection \\
\hline 8004/pGUS2736 & 8004 harboring pGUS2736, $\operatorname{Rif}^{\mathrm{r}} \mathrm{Tet}^{\mathrm{r}}$ & This work \\
\hline 8004/pGUShrpA & 8004 harboring pGUShrpA, $\operatorname{Rif}^{\mathrm{r}} \operatorname{Tet}^{\mathrm{r}}$ & This work \\
\hline 8004/pGUShrpB & 8004 harboring pGUShrpB, $\operatorname{Rif}^{\mathrm{r}} \operatorname{Tet}^{\mathrm{r}}$ & This work \\
\hline 8004/pGUShrpC & 8004 harboring pGUShrpC, $\operatorname{Rif}^{\mathrm{r}} \mathrm{Tet}^{\mathrm{r}}$ & This work \\
\hline 8004/pGUShrpD & 8004 harboring pGUShrpD, Rif $^{\mathrm{r}} \mathrm{Tet}^{\mathrm{r}}$ & This work \\
\hline 8004/pGUShrpE & 8004 harboring pGUShrpE, Rif $^{\mathrm{r}}$ Tet $^{\mathrm{r}}$ & This work \\
\hline 8004/pGUShrpF & 8004 harboring pGUShrpF, $\operatorname{Rif}^{\mathrm{r}} \operatorname{Tet}^{\mathrm{r}}$ & This work \\
\hline 8004/pGUShrpG & 8004 harboring pGUShrpG, $\operatorname{Rif}^{\mathrm{r}} \operatorname{Tet}^{\mathrm{r}}$ & This work \\
\hline 8004/pGUShrpX & 8004 harboring pGUShrpX, Rif $^{\mathrm{r}}$ Tet $^{\mathrm{r}}$ & This work \\
\hline 8004/pGUSA & 8004 harboring pGUSA, Rif $^{\mathrm{r}}$ Tet $^{\mathrm{r}}$ & This work \\
\hline $8004 / p R 3 G$ & 8004 harboring pR3G, $\operatorname{Rif}^{\mathrm{r}} \mathrm{Tet}^{\mathrm{r}}$ & This work \\
\hline 8004G/pGUS2736 & 8004G harboring pGUS2736, $\operatorname{Rif}^{\mathrm{r}} \operatorname{Kan}^{\mathrm{r}} \operatorname{Tet}^{\mathrm{r}}$ & This work \\
\hline $8004 X / p G U S 2736$ & 8004X harboring pGUS2736, $\operatorname{Rif}^{\mathrm{r}} \operatorname{Kan}^{\mathrm{r}} \operatorname{Tet}^{\mathrm{r}}$ & This work \\
\hline 8004/pLAFR3 & 8004 harboring pLAFR3, $\operatorname{Rif}^{\mathrm{r}} \mathrm{Tet}^{\mathrm{r}}$ & This work \\
\hline 2736nk/pGUS2736 & 2736nk harboring pGUS2736, $\operatorname{Rif}^{\mathrm{r}} \operatorname{Kan}^{\mathrm{r}} \operatorname{Tet}^{\mathrm{r}}$ & This work \\
\hline 2736nk/pGUShrpA & 2736nk harboring pGUShrpA, $\operatorname{Rif}^{\mathrm{r}} \operatorname{Kan}^{\mathrm{r}} \operatorname{Tet}^{\mathrm{r}}$ & This work \\
\hline 2736nk/pGUShrpB & 2736nk harboring pGUShrpB, $\operatorname{Rif}^{\mathrm{r}} \operatorname{Kan}^{\mathrm{r}} \operatorname{Tet}^{\mathrm{r}}$ & This work \\
\hline 2736nk/pGUShrpC & 2736nk harboring pGUShrpC, $\operatorname{Rif}^{\mathrm{r}} \operatorname{Kan}^{\mathrm{r}} \operatorname{Tet}^{\mathrm{r}}$ & This work \\
\hline 2736nk/pGUShrpD & 2736nk harboring pGUShrpD, $\operatorname{Rif}^{\mathrm{r}} \operatorname{Kan}^{\mathrm{r}} \operatorname{Tet}^{\mathrm{r}}$ & This work \\
\hline 2736nk/pGUShrpE & 2736nk harboring pGUShrpE, $\operatorname{Rif}^{\mathrm{r}} \operatorname{Kan}^{\mathrm{r}} \operatorname{Tet}^{\mathrm{r}}$ & This work \\
\hline 2736nk/pGUShrpF & 2736nk harboring pGUShrpF, $\operatorname{Rif}^{\mathrm{r}} \operatorname{Kan}^{\mathrm{r}} \operatorname{Tet}^{\mathrm{r}}$ & This work \\
\hline 2736nk/pGUShrpG & 2736nk harboring pGUShrpG, $\operatorname{Rif}^{\mathrm{r}} \operatorname{Kan}^{\mathrm{r}} \operatorname{Tet}^{\mathrm{r}}$ & This work \\
\hline 2736nk/pGUShrpX & 2736nk harboring pGUShrpX, $\operatorname{Rif}^{\mathrm{r}} \operatorname{Kan}^{\mathrm{r}} \operatorname{Tet}^{\mathrm{r}}$ & This work \\
\hline $2736 \mathrm{nk} / \mathrm{pR} 3 \mathrm{G}$ & 2736nk harboring pR3G, $\operatorname{Rif}^{\mathrm{r}} \mathrm{Kan}^{\mathrm{r}} \mathrm{Tet}^{\mathrm{r}}$ & This work \\
\hline 2736nk/pGUSA & 2736nk harboring pGUSA, $\operatorname{Rif}^{\mathrm{r}} \operatorname{Kan}^{\mathrm{r}} \operatorname{Tet}^{\mathrm{r}}$ & This work \\
\hline 2736nk/pLAFR3 & 2736nk harboring pLAFR3, $\operatorname{Rif}^{\mathrm{r}} \mathrm{Kan}^{\mathrm{r}} \mathrm{Tet}^{\mathrm{r}}$ & This work \\
\hline \multicolumn{3}{|l|}{ Plasmids } \\
\hline pLAFR3 & Broad host range cloning vector, Tet $^{\mathrm{r}}$ & Staskawicz et al. 1987 \\
\hline pRK2073 & Helper plasmid, $\mathrm{Tra}^{+}, \mathrm{Mob}^{+}, \mathrm{ColE} 1, \mathrm{Spc}^{\mathrm{r}}$ & Leong et al. 1982 \\
\hline $\mathrm{pK} 18 m o b$ & pUC18 derivative, $l a c Z \alpha \operatorname{Kan}^{\mathrm{r}}, m o b$ site; suicide plasmid in & \\
\hline & $X$. campestris pv. campestris & Schäfer et al. 1994 \\
\hline pL2736 & 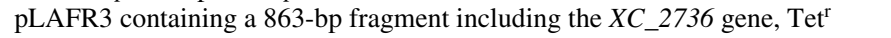 & This work \\
\hline pL6gus & pLAFR6 containing a 1,832-bp gusA ORF (excluding ATG), Tet ${ }^{\mathrm{r}}$ & Jiang et al. 2008 \\
\hline $\mathrm{pR} 3 \mathrm{G}$ & $\begin{array}{l}\text { pLAFR3 containing an 899-bp fragment including promoterless } h r p G \text { gene, } \\
\operatorname{Tet}^{r}\end{array}$ & Huang et al. 2009 \\
\hline pGUS2736 & $\begin{array}{l}\text { pLAFR6 containing the promoter region of the } X C_{-} 2736 \text { fused to the coding } \\
\text { region for } g u s A, \mathrm{Tet}^{\mathrm{r}}\end{array}$ & This work \\
\hline pGUShrpA & pLAFR6 containing an $h r p A$ operon promoter-gusA fusion fragment, Tet ${ }^{\mathrm{r}}$ & Laboratory collection \\
\hline pGUShrpB & pLAFR6 containing an $h r p B$ operon promoter-gusA fusion fragment, Tet ${ }^{\mathrm{r}}$ & Laboratory collection \\
\hline pGUShrpC & pLAFR6 containing an $h r p C$ operon promoter-gusA fusion fragment, Tet $^{\mathrm{r}}$ & Laboratory collection \\
\hline pGUShrpD & pLAFR6 containing an $h r p D$ operon promoter-gusA fusion fragment, Tet ${ }^{\mathrm{r}}$ & Laboratory collection \\
\hline pGUShrpE & pLAFR6 containing an $h r p E$ operon promoter-gusA fusion fragment, Tet ${ }^{\mathrm{r}}$ & Laboratory collection \\
\hline pGUShrpF & pLAFR6 containing an $h r p F$ operon promoter-gusA fusion fragment, Tet ${ }^{\mathrm{r}}$ & Laboratory collection \\
\hline pGUShrpG & pLAFR6 containing an $h r p G$ promoter-gusA fusion fragment, Tet $^{r}$ & Laboratory collection \\
\hline pGUShrpX & pLAFR6 containing an $h r p X$ promoter-gusA fusion fragment, Tet $^{\mathrm{r}}$ & Laboratory collection \\
\hline pGUSA & pLAFR6 containing a full DNA fragment of gusA gene, Tet $^{\mathrm{r}}$ & Laboratory collection \\
\hline
\end{tabular}

${ }^{\mathrm{a}} \mathrm{Rif}^{\mathrm{r}}, \mathrm{Kan}^{\mathrm{r}}, \mathrm{Tet}^{\mathrm{r}}$, and $\mathrm{Spc}^{\mathrm{r}}$ indicate resistance to rifampicin, kanamycin, tetracycline, and spectinomycin, respectively. 
ble S1). Transcriptional products spanning any two adjacent ORF could be detected, suggesting that these ORF may share an operon. To confirm this finding, we constructed a mutant (named 2736pk) with a polar effect in the first ORF XC_2736 of the presumed operon (details below). The transcriptional products within the five ORF ( $X C \_2737$ to $X C \_2741$ ) were then analyzed in the polar-effect mutant described previously (2736pk) as well as the nonpolar-effect mutant (2736nk) by RT-PCR. As expected, RT-PCR products from all of the five examined ORF were detected in the nonpolar mutant 2736nk, whereas no RT-PCR product from any of the five ORF could be detected in the polar mutant 2736pk. Taken together, these data demonstrate that the ORF XC_2736 to XC_2741 are cotranscribed and form an operon. In addition, we compared the virulence and ability to elicit HR of the polar mutant with those of the nonpolar mutant. The result showed that the disease symptoms and HR induced by the two mutant strains were almost identical (data not shown).

Using a standard $5^{\prime}$ rapid amplification of cDNA ends (RACE) method (details below), the transcription initiation site of the operon was mapped at 280 nucleotides (nt) upstream of the $X C \_2736$ start codon ATG. No typical -10 and -35 consensus sequences were observed; however, the nucleotide sequences from -13 to -8 (TATAGT) and -35 to -30 (TTGACT) might represent the -10 and -35 sequences, respectively. A putative Shine-Dalgarno sequence (ACGGAGC) lies $254 \mathrm{bp}$ upstream of the $X C_{\_} 2736$ ATG start codon. The DNA sequence from 251 to $2 \mathrm{nt}$ upstream of the $X C_{-} 2736$ start codon might compose a small ORF, which was not annotated in $X$. campestris pv. campestris 8004 (Qian et al. 2005) and ATCC 33913 (da Silva et al. 2002) but was annotated in X. campestris pv. campestris B100 to encode a hypothetical protein (named Xccb100_2772) (Vorhölter et al. 2008).

\section{HpaR1 negatively affects the expression of hrp genes in standard media.}

As described above, in $X$. campestris pv. campestris, the induction of HR in the nonhost plant is governed by a cluster of hrp genes, the expression of which is positively controlled by the key regulators HrpG and HrpX. It has been demon-

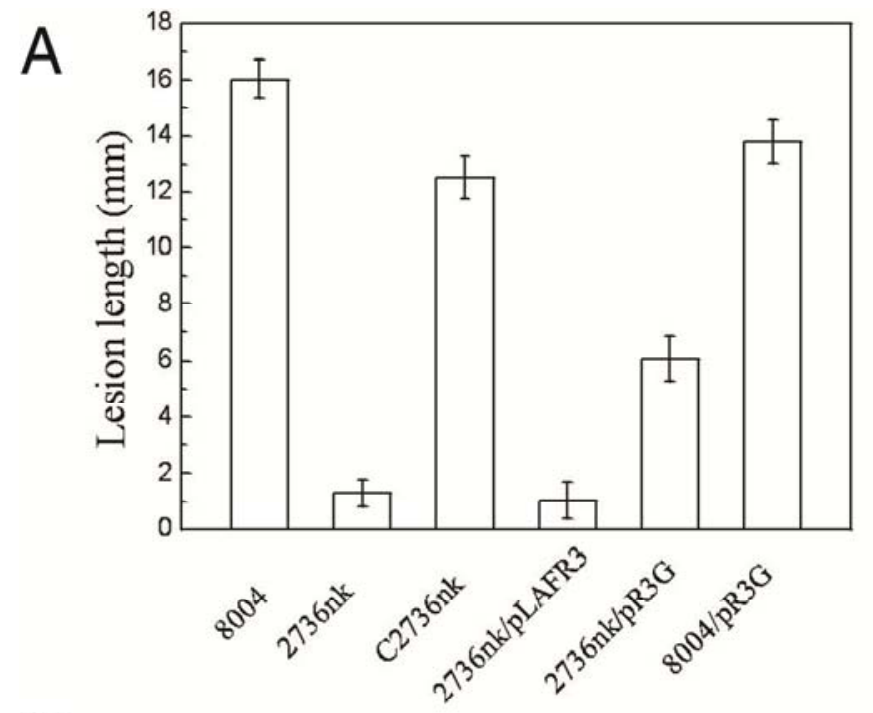

C

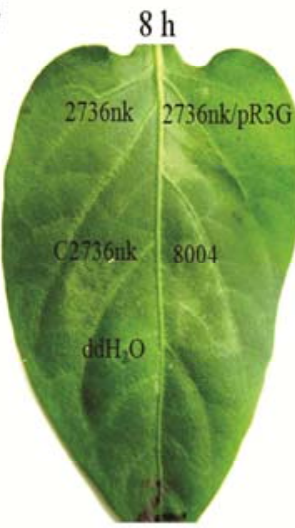

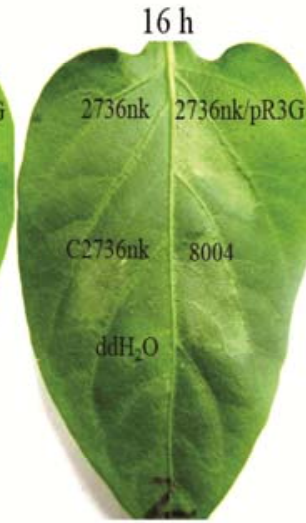

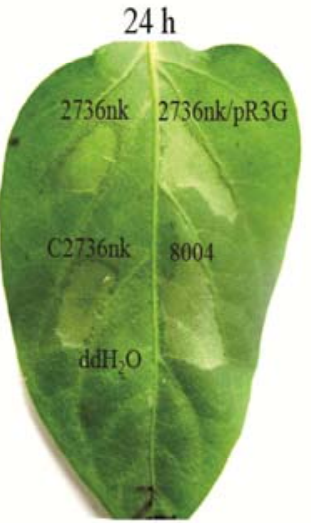

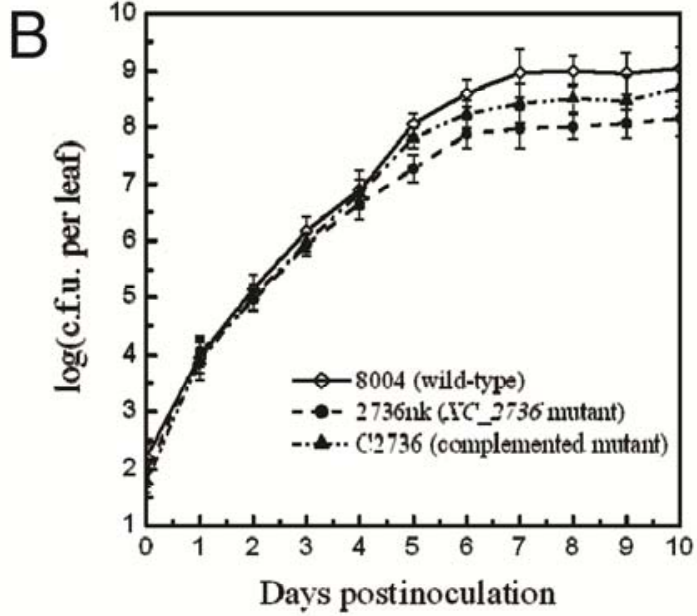

$\mathrm{D}$

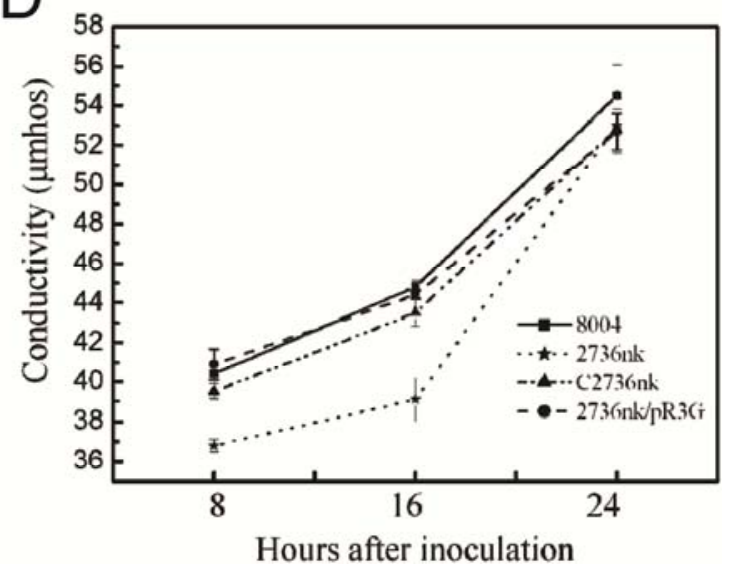

Fig. 2. XC_2736 is involved in virulence and hypersensitive response of Xanthomonas campestris pv. campestris. A, Mean lesion lengths caused by different $X$. campestris pv. campestris strains. Values given are the means and standard deviations from 15 measurements. B, Bacterial populations of the mutant 2736nk, wild-type 8004, and complemented mutant C2736 in host plant leaves. Inoculated leaves for each strain were taken daily and homogenized in sterile water. The homogenates were diluted and plated on NYG (Daniels et al. 1984a) plates. Bacterial CFU were counted after incubation for 3 days. Data are the means and standard deviations from three replicates. $\mathbf{C}$, Hypersensitive response symptoms induced in pepper leaves (Capsicum annuит cv. ECW-10R) by the $X$. campestris pv. campestris strains. Approximately 5 - $\mu \mathrm{l}$ bacterial cultures $\left(1 \times 10^{7} \mathrm{CFU} / \mathrm{ml}\right)$ suspended in $10 \mathrm{mM}$ sodium phosphate buffer were infiltrated into the leaf mesophyll tissue with a blunt-end plastic syringe. Pictures of the pepper leaf were taken at 8 , 16 , and 24 h after infiltration. Three replications were done in each experiment, and each experiment was repeated three times. Results presented are from a representative experiment, and similar results were obtained in all other independent experiments. D, Electrolyte leakage from pepper leaves inoculated with $X$. campestris pv. campestris strains was measured. Results presented are from a representative experiment, and similar results were obtained in other independent experiments. 
strated that the expression of $X$. campestris pv. campestris hrp genes, including $h r p G$ and $h r p X$, is significantly enhanced in minimal medium MMX and plant tissues (Wei et al. 2007). To investigate whether the HR and virulence attenuations caused by a mutation in $h p a R l$ is attributed to interference in hrp gene expression, we compared the hrp gene expression levels in the hpaRl mutant and the wild type. The promoter-gusA transcriptional fusion reporters of $X$. campestris pv. campestris $h r p G$ and $h r p X$ (Table 1) were constructed and introduced by triparental conjugation into the hpaRl mutant strain $2736 \mathrm{nk}$ and the wild-type strain 8004, respectively (details below). Subsequently, $\beta$-glucuronidase (GUS) activity in the resulting reporter strains (Table 1) was tested in rich medium NYG and minimal medium MMX. The result showed that GUS activity in the hrpG-gus and hrpX-gus reporters pGUShrpG and pGUShrpX in hpaRl mutation background was significantly $(P=0.01$ by $t$ test) higher than activity in the wild-type background in both media (Fig. 3A). Moreover, GUS activity of the reporter pGUShrpX in hpaRl mutant background was approximately fourfold higher than that in the wild-type background grown in MMX medium. Reporters of the six hrp operons ( $h r p A$ to $h r p F)$ (Table 1) were also introduced into both the hpaRl mutant strain and the wild-type strain. Similarly, the GUS activity of all these reporters in hpaRl mutation background was also significantly $(P=0.01$ by $t$ test) higher than activity in the wild-type background (Fig. 3A). A real-time quantitative PCR method was used to compare the $h r p G$ and $h r p X$ transcriptional levels in the hpaRl mutant and the wild type in MMX medium. The $h r p G$ and $h r p X$ transcript levels in the hpaRl mutant were approximately 1.3-fold and 17.4-fold higher, respectively, than in the wild-type strain (Fig. 3B). Taken together, these findings reveal that HpaR1 has a negative effect on the expression of $h r p$ genes, including the key regulators $h r p G$ and $h r p X$ in $X$. campestris pv. campestris grown in standard media.

Simultaneously, we also evaluated whether HrpG and HrpX have an effect on hpaRl expression. For this purpose, an hpaRl reporter plasmid (pGUS2736) for transcriptional analysis was constructed, on which a 470-bp DNA fragment harboring the hpaRl promoter sequence was cloned into the plasmid pL6gus that harbors the promoterless gusA gene in the BamHI/SphI sites of pLARF6 (Jiang et al. 2008). Subsequently, the reporter plas- mid pGUS2736 was introduced by triparental conjugation into the $h r p G$ or $h r p X$ deletion mutants $8004 \mathrm{G}$ and $8004 \mathrm{X}$, as well as the wild-type strain 8004. The resulting strains 8004G/ pGUS2736, 8004X/pGUS2736, and 8004/pGUS2736 were cultured in MMX medium. After a 24-h incubation, the GUS activity in each strain was assayed at 12-h intervals until $60 \mathrm{~h}$ after incubation. No significant difference was observed in the GUS activities among the three strains at each of the test time points (data not shown), indicating that HrpG and HrpX may not have an impact on the expression of hpaRl.

\section{HpaR1 positively affects the expression of hrp genes in planta.}

A minimal medium has been commonly used to mimic plant cell conditions for studies on pathogen-plant interactions. However, the plant tissue environment including, cellular components, is much more complex than a minimal medium. To further explore whether the hrp gene expression of $X$. campestris pv. campestris in host plant tissues is also negatively affected by HpaR1, the wild-type and hpaRl-mutant strains harboring hrpG-gus, hrpX-gus, or $h r p F$-gus reporter (as a representative for $h r p A$ to $h r p F$ operons) were inoculated into the host plant Chinese radish using the leaf-clipping method, and GUS activity in the infected tissues was detected at 4 days postinoculation. The leaf tissue inoculated with 8004/pGUShrpG, 8004/pGUShrpX, or 8004/pGUShrpF became dark blue, whereas no blue color was observed in the leaves inoculated with 2736nk/pGUShrpG, 2736nk/pGUShrpX, or $2736 \mathrm{nk} / \mathrm{pGUShrpF}$ (Fig. 4A), indicating that the disruption of hpaRl negatively influenced $X$. campestris pv. campestris hrp gene expression. In addition, the CFU numbers of the tested strains inside the infected leaves were determined, and the result showed that they were similar (Fig. 4A). The method described by Vojnov and associates (2001) was used to further quantify the GUS activity of the strains in the plant. The GUS activity produced by the strains 2736nk/pGUShrpG, 2736nk/ pGUShrpX, and 2736nk/pGUShrpF was significantly lower than activity produced by the strains 8004/pGUShrpG, 8004/ pGUShrpX, and 8004/pGUShrpF, respectively (Fig. 4B). These combined data reveal that HpaR1 plays a positively regulatory role in the expression of hrp genes in host plants; contrary to the mode of action in standard media.
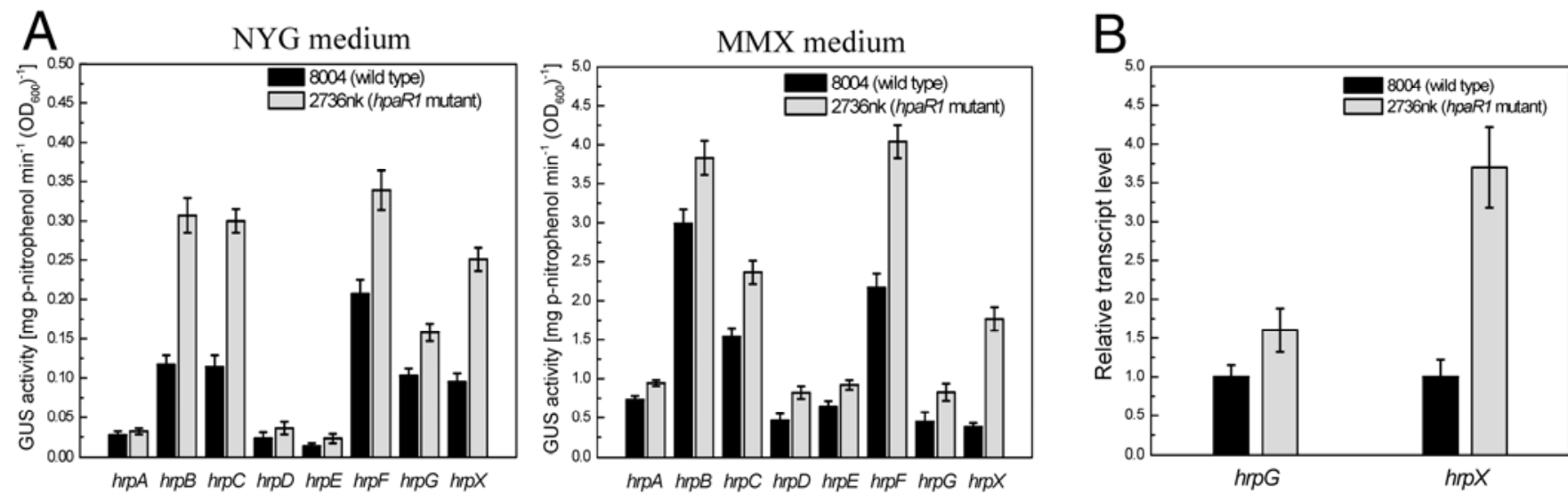

Fig. 3. HpaR1 negatively affects the expression of hypersensitive response and pathogenicity ( $h r p$ ) genes in standard media. A, $\beta$-Glucuronidase (GUS) activity of hrp promoter-gusA reporters in the hpaRl mutant and the wild-type backgrounds. Xanthomonas campestris pv. campestris strains were cultured in medium NYG and MMX (Daniels et al. 1984a) for 16 and 48 h, respectively, and GUS activities were then determined by measurement of optical density at $415 \mathrm{~nm}\left(\mathrm{OD}_{415}\right)$ using $\rho$-nitrophenyl- $\beta$-D-glucuronide as substrate. Data are means \pm standard deviations of triplicate measurements. The experiment was repeated twice, and similar results were obtained. B, Real-time quantitative polymerase chain reaction analysis of the transcription of $h r p G$ and $h r p X$. RNA was isolated from cultures of X. campestris pv. campestris wild-type strain 8004 and the hpaR1 mutant strain $2736 \mathrm{nk}$ grown in MMX medium for $48 \mathrm{~h}$. The relative mRNA level was calculated with respect to the level of the corresponding transcript in wild-type strain 8004 (equaling 1). Values given are the means \pm standard deviations of triplicate measurements from a representative experiment; similar results were obtained in two other independent experiments. 
HpaR1 affects the expression of $h r p$ genes through $h r p G$.

Previous experimental evidence has demonstrated that, in $X$. campestris pv. campestris, $\mathrm{HrpG}$ activates the expression of $h r p X$, and HrpX then regulates the expression of $h r p A$ to $h r p F$ operons (Huang et al. 2009). The findings described here reveal an important role for HpaR1 regulator in the expression of these $h r p$ genes. It is probable that HpaR1 regulates $h r p X$ and $h r p A$ to $h r p F$ operons through HrpG. To evaluate this possibility, the recombinant plasmid pR3G that constitutively expresses $h r p G$ (Table 1) was introduced into the hpaRl mutant 2736nk by triparental conjugation. The plasmid pR3G was previously constructed by cloning the $X$. campestris pv. campestris promoterless hrpG with its own authentic ribosomal binding site (RBS) into pLAFR3. The plasmid pLAFR3 is a low-copy-number vector with an Escherichia coli lac promoter flanking the multiple cloning sites (Huynh et al. 1989), which expresses constitutively in $X$. campestris pv. campestris (Huang et al. 2009). The promoterless hrpG was cloned into pLAFR3 in an orientation that allowed the $h r p G$ to be driven by the lac promoter (Huang et al. 2009). The HR induction of the obtained transconjugant strain $2736 \mathrm{nk} / \mathrm{pR} 3 \mathrm{G}$ was determined in the nonhost plant pepper ECW-10R. The results demonstrated that the strain $2736 \mathrm{nk} / \mathrm{pR} 3 \mathrm{G}$ could elicit a wild-type HR symptom in the nonhost plant (Fig. 2C and D), indicating that the HR-induction capacity of the hpaRl mutant could be completely restored by constitutively expressing hrpG.

The virulence of the strain $2736 \mathrm{nk} / \mathrm{pR} 3 \mathrm{G}$ was also examined on the host plant Chinese radish. Interestingly, the mean lesion length caused by the strain 2736nk/pR3G was far shorter than that produced by the wild type, although it was significantly longer ( $t$ test, $P=0.01$ ) than lesions produced by the mutant strain 2736nk (Fig. 2A). These data imply that constitutively expressing $h r p G$ could only partially restore the virulence of the hpaR1 mutant 2736nk. The stability of the recombinant plasmid $\mathrm{pR} 3 \mathrm{G}$ in the mutant 2736nk in planta was assessed. To our surprise, 6 days after inoculation, $45.5 \%$ of the bacterial cells of the strain $2736 \mathrm{nk} / \mathrm{pR} 3 \mathrm{G}$ recovered from the infected leaves had lost the recombinant plasmid pR3G. These data suggest that the plasmid pR3G was quite unstable in the mutant, which might be one explanation for the phenomenon that constitutively expressing $h r p G$ could only partially restore the virulence of the mutant. Another possibility might be that constitutive expression of $h r p G$ is deleterious. In either case, the fact that constitutively expressing $h r p G$ in the hpaRl mutant could bypass the requirement of HpaR1 for the induction of wild-type HR reveals that HpaR1 affects the expression of hrp genes through HrpG.

\section{HpaR1 can autoregulate its own transcription level.}

As described above, the GntR member HpaR1 encoded by the ORF XC_2736 belongs to the YtrA subfamily (Fig. 1B). A palindromic sequence (GT..TA.....TA..AC) has been proposed to be the binding site for the YtrA subfamily members of GntR regulators (Rigali et al. 2002). A scan of the nucleotide sequence upstream of the translation start codon of $X C \_2736$ revealed the presence of such palindromic sequences (GTTGAAT......ATCCAAC) in the promoter region. To study whether HpaR1 interacts directly with its own promoter sequence, a $\mathrm{His}_{6}$-HpaR1 protein was constructed and expressed in $E$. coli by isopropyl-thio-galactopyranoside (IPTG) induction (details below). The purified His ${ }_{6}$-HpaR1 protein and a 470-bp DNA fragment encompassing the hpaRl promoter were used to ascertain their interaction by electrophoretic mobility shift assay (EMSA) (details below). The result showed that the $\mathrm{His}_{6}$-HpaR1 protein retarded the promoter se- quence to a defined position (Fig. 5A), whereas an extract from $E$. coli carrying the His ${ }_{6}$-HpaR1 construction without IPTG induction did not (data not shown). A DNA fragment internal to the HpaR1-coding sequence, added as a negative control to each assay, was not bound by the His ${ }_{6}$-HpaR1 (Fig. 5A). These data suggest that HpaR1 may directly interact with its own promoter.

To gain insight into the regulatory role of HpaR 1 in its own expression, we performed an in vitro transcription assay to investigate whether HpaR1 can activate or repress the transcription of hpaRl gene (details below). The transcription of hpaRl did not require HpaR 1 protein in vitro, and the in vitro transcription levels of $h p a R l$ decreased along with increase of the $\mathrm{His}_{6}-\mathrm{HpaR} 1$ protein concentrations in the reaction (Fig. 5B). These results suggest that HpaR1 can repress its own transcription level in vitro.

To further analyze the expression profile of hpaRl, the reporter plasmid of hpaRl, pGUS2736, was introduced into the wild-type strain 8004 and the hpaRl mutant 2736nk. The resulting reporter strains 8004/pGUS2736 and 2736nk/ pGUS2736 were cultured in rich medium NY and minimal medium MMX, and GUS activity was measured for each. The results showed that the GUS activity of the 2736nk/pGUS2736 strain was significantly higher than that of the 8004/pGUS2736 strain in both media (Fig. 5C). These data indicate that HpaR1 can repress its own expression in vivo when the bacterial cells are grown in standard media. To clarify whether HpaR1 negatively regulates its own expression inside the host plant, the reporter strains were introduced into Chinese radish leaves by leaf clipping and the GUS activities in the infected tissues were detected every day from 3 to 7 days postinoculation. Blue color appeared 3 days postinoculation in the infected tissue of the leaves inoculated with the reporter strain 8004/pGUS2736 and the color became darker and darker day by day (Fig. 5D); however, no distinct blue color was observed in the leaves inoculated with $2736 \mathrm{nk} / \mathrm{pGUS} 2736$ even 7 days postinoculation. Further quantification of GUS activity showed that the expression of the reporter pGUS2736 in the hpaRl mutant background was significantly lower than that in the wild-type background (Fig. 5D). The results suggest that HpaR1 can enhance its own expression in vivo when the bacterial cells are inside the host plant.

\section{HpaR1 may regulate the expression of $h r p G$ indirectly.}

The results described above have demonstrated that HpaR1 plays an important role in the regulation of $h r p G$ expression as well as the autoregulation of its own expression by directly binding to its own promoter region. To verify whether HpaR 1 regulates $h r p G$ expression by directly binding to the $h r p G$ promoter, we determined whether the HpaR1 protein and the $h r p G$ promoter sequence interact with each other by EMSA. A 638-bp DNA fragment containing the hrpG promoter was amplified by PCR using the total DNA of the $X$. campestris pv. campestris wild-type strain 8004 as a template and the corresponding primers. The ability of the purified His $_{6}-\mathrm{HpaR}_{1}$ to bind this DNA fragment was then analyzed by EMSA under the conditions for the binding of $\mathrm{His}_{6}$ HpaR 1 to its own promoter, as described above. A 677-bp DNA fragment containing the $h r p X$ promoter was also included in a parallel experiment. The result showed that the $\mathrm{His}_{6}-\mathrm{HpaR} 1$ protein did not bind to the $h r p G$ or $h r p X$ promoter-containing sequence (data not shown). This suggests that HpaR1 may regulate $h r p G$ indirectly. An alternative possibility is that the binding of $\mathrm{HpaR} 1$ protein with the hrpG promoter needs other conditions, such as a special effector molecule, which may be present in vivo. 


\section{DISCUSSION}

This study has revealed that the GntR family transcriptional regulator HpaR1 of $X$. campestris pv. campestris is implicated in HR and virulence. Although the presence of other regulatory targets remains a possibility, we have demonstrated that HpaR1 regulates the expression of $h r p$ genes that encode T3SS via the key $h r p$ regulator HrpG. The GntR family of transcriptional regulators is named after the gluconate operon transcriptional repressor GntR of Bacillus subtilis, which was previously described by Haydon and Guest (1991). As reviewed by Hoskisson and Rigali (2009), the members of this family are widely distributed throughout bacteria and play important roles in regulating many diverse biological processes such as primary metabolism, motility, development, antibiotic production and resistance, plasmid transfer, and virulence. Comparatively, most characterized GntR members are associated with metabolism and only a few with virulence. Virulence-related GntR members have only been described in M. tuberculosis and Brucella melitensis to date. Casali and associates (2006) have demonstrated that the FadR subfamily member Mce1R regulates the mammalian cell entry (mce) genes of $M$. tuberculosis, and the mce $1 R$ mutant elicits an aberrant granulomatous response, resulting in uncontrolled replication and failure to enter a persistent state in murine models. Systematic targeted mutagenesis of $B$. melitensis has identified three GntR regulators that are involved in virulence, although their regulon remains to be further elucidated (Haine et al. 2005). As described above, all of the three sequenced $X$. campestris pv. campestris strains possess six ORF that encode putative GntR regulators. In addition, our previous array-based comparative genome hybridization analyses indicated that the six ORF are highly conserved in all of the 18 other $X$. campestris pv. campestris strains tested (He et al. 2007). These findings suggest that GntR regulators may be widely distributed among $X$. campestris pv. campestris bacteria. In addition to construction of the hpaRl mutant, we have also successfully constructed mutants for all other predicted GntR-encoding ORF except one that could not be disrupted. This lays a foundation for further exploration of the function of GntR regulators in $X$. campestris pv. campestris.

It has been well established that the T3SS plays a crucial role in the pathogenicity of many gram-negative bacterial pathogens of plants and animals via injecting important effector proteins into host cells (Alfano and Collmer 2004; Cornelis and Van Gijsegem 2000; Hueck 1998; Lindgren 1997). The regulatory mechanisms of T3SS expression in many pathogens have been extensively studied, leading to the identification of a large number of regulators (Cornelis and Van Gijsegem 2000; Mole et al. 2007). The identified regulators include many transcriptional factors; however, almost all of them belong to families other than the GntR. Thus far, there is only one report

\section{A}
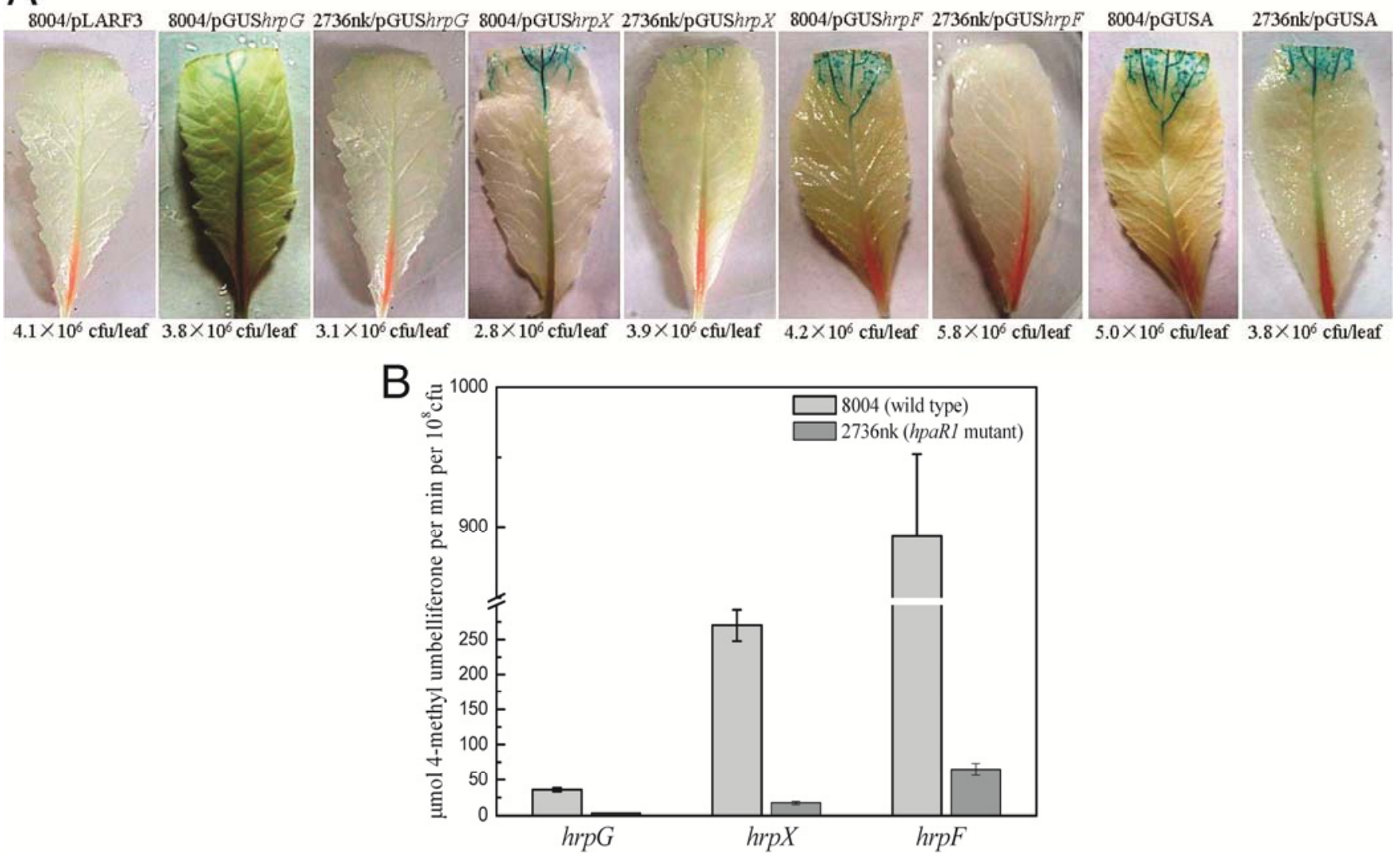

Fig. 4. HpaR1 affects positively the expression of hypersensitive response and pathogenicity (hrp) genes in a host plant. Xanthomonas campestris pv. campestris strains 8004/pGUShrpG, 8004/pGUShrpX, 8004/pGUShrpF, 2736nk/pGUShrpG, 2736nk/pGUShrpX, and 2736nk/pGUShrpF were cultured in NYG (Daniels et al. 1984a) liquid medium overnight and resuspended in water to an optical density at $600 \mathrm{~nm}$ of 0.1 and were then inoculated into the Chinese radish (Raphanus sativus) leaves by leaf clipping. At 4 days postinoculation, the inoculated leaves were assayed. A, $\beta$-Glucuronidase (GUS) activity was measured using an in situ staining method, and bacterial cell numbers inside the infected leaves were measured in a parallel experiment. X. campestris pv. campestris strains harboring the plasmid pLAFR3 or pGUSA (harboring the gusA gene) were tested as controls. Average bacterial numbers inside the tested leaves are indicated. The experiments were repeated twice. Data presented are from a representative experiment, and similar results were obtained in two other independent experiments. B, GUS activity was measured following the method developed by Vojnov and associates (2001). Leaves were taken and analyzed for bacterial numbers and for GUS activity measured with the fluorogenic substrate 4-methylumbelliferyl- $\beta$-D-glucuronide. GUS activity values per bacterial cell are the means and standard deviations of three independent measurements. 
A

A

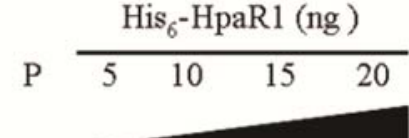

C1

C2

B

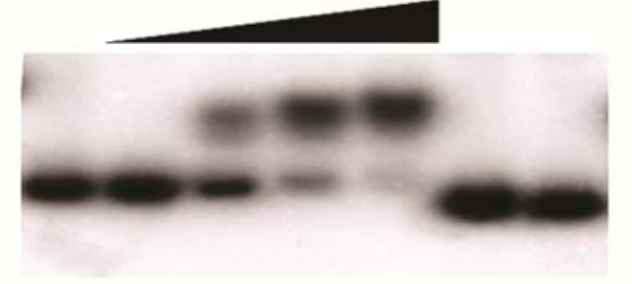

C

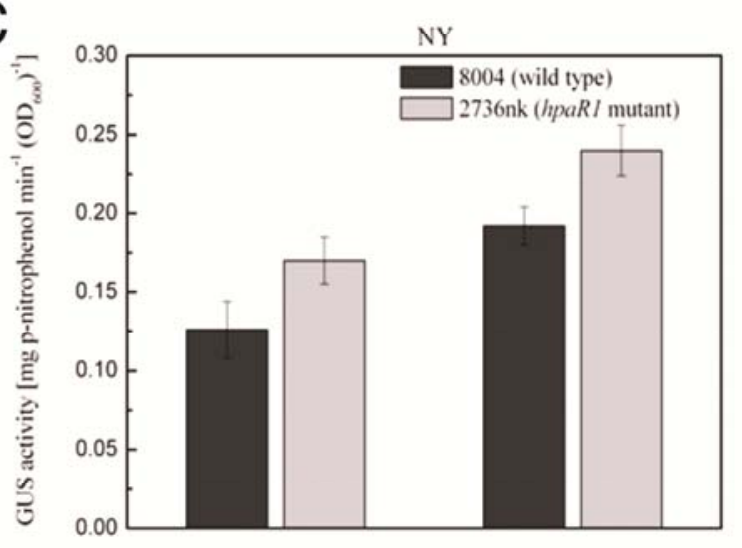

24

D
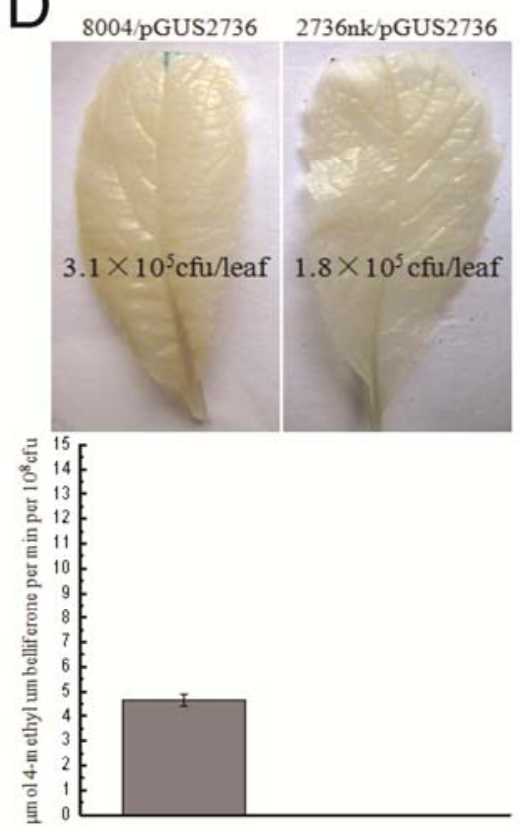

$3 \mathrm{~d}$
36
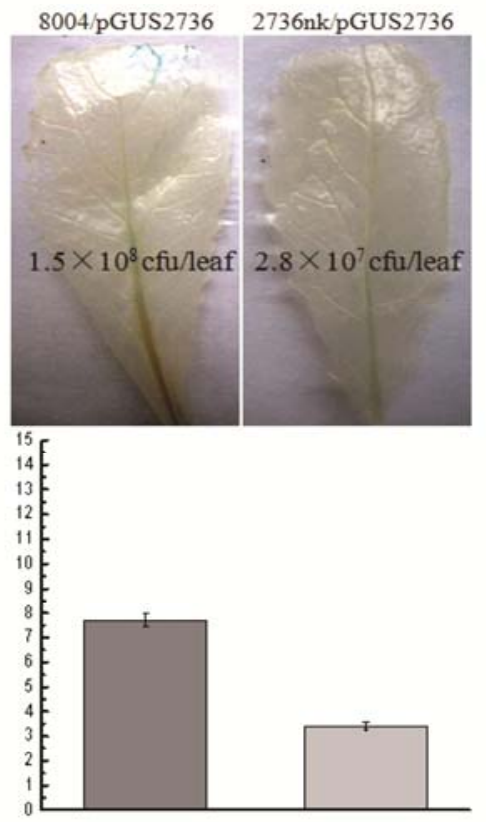

$5 \mathrm{~d}$
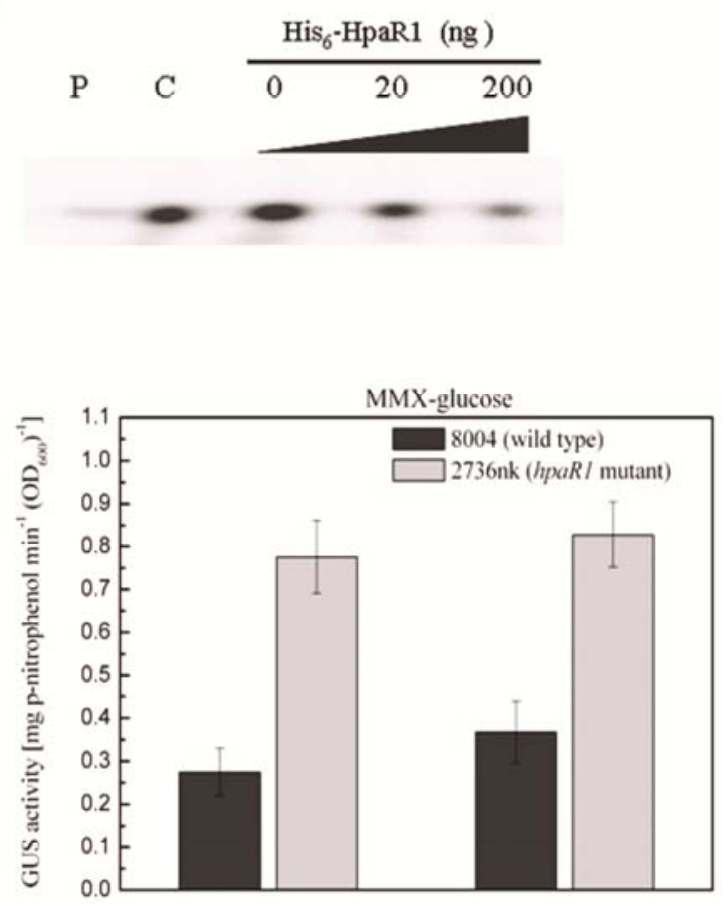

36

48
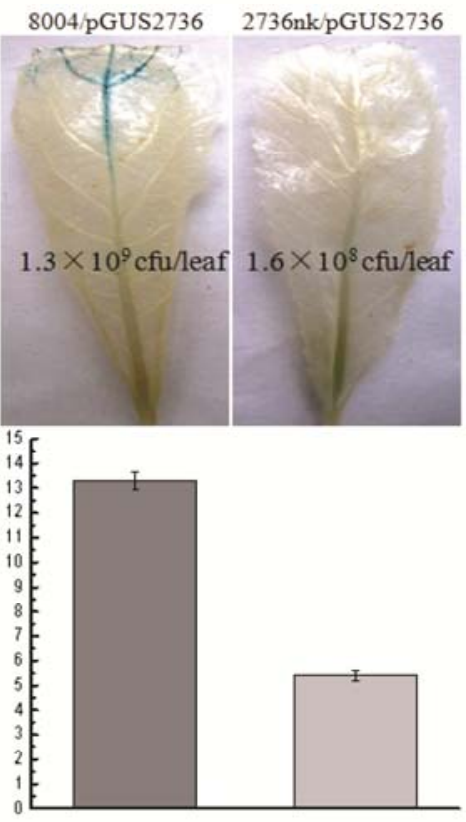

$7 \mathrm{~d}$

Fig. 5. HpaR1 directly regulates its own expression. A, Determination of HpaR1-binding to its own promoter region by electrophoretic mobility shift assay. ${ }^{32} \mathrm{P}$-labeled fragment was incubated with $5,10,15$, or $20 \mu \mathrm{g}$ of purified $\mathrm{His}_{6}-\mathrm{HpaR} 1$ protein. P, ${ }^{32} \mathrm{P}-$ labeled hpaR1 promoter DNA probe; C1, control probe (internal to the HpaR1 coding sequence) alone; C2, control probe with $50 \mu \mathrm{g}$ of purified $\mathrm{His}_{6}{ }_{6} \mathrm{HpaR}_{1}$ protein. B, Purified His ${ }_{6} \mathrm{HpaR}^{-\mathrm{H}}$ protein represses the transcription of the promoter of $h p a R l$ in vitro. RNA was generated in vitro from a polymerase chain reaction product template containing the promoter as well as 195 bp downstream of the start codon ATG (including ATG) of the hpaR1 gene. For in vitro transcription, templates incubated with 0, 20, or 200 ng of $\mathrm{His}_{6}$ - $\mathrm{HpaR} 1$ protein before the start of transcription on addition of $1 \mathrm{U}$ of RNA polymerase are shown. P, DNA templates without addition of RNAP; $\mathrm{C}$,

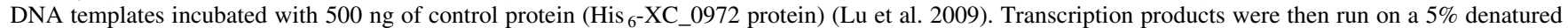
polyacrylamide gel containing $7 \mathrm{M}$ urea in 1× Tris borate-EDTA electrophoresis buffer. C, GUS activities of the hpaR1 reporter plasmid pGUS2736 in the hpaR1 mutant and wild-type backgrounds. Xanthomonas campestris pv. campestris strains were cultured in the rich medium NY for 24 and $36 \mathrm{~h}$ and in the minimal medium MMX (Daniels et al. 1984a) for 36 and $48 \mathrm{~h}$, and then GUS activities were determined. Data are means \pm standard deviations of triplicate measurements. The experiment was repeated twice, and similar results were obtained. D, HpaR1 is essential for the expression of $h p a R 1$ in the host plant. $X$. campestris pv. campestris strains 8004/pGUS2736 and 2736nk/pGUS2736 were inoculated into the Chinese radish (Raphanus sativus) leaves. At 3, 5, and 7 days postinoculation, the GUS activity was measured by using 5-bromo-4-chloro-3-indolylglucuronide (Jefferson et al. 1987) and 4-methylumbelliferyl- $\beta$-Dglucuronide (Vojnov et al. 2001) as a substrate, respectively. GUS activity values per bacterial cell are the means and standard deviations of three independent measurements. 
of a GntR member that is involved in hrp regulation. By transposon mutagenesis, Tsuge and associates (2006) have identified a predicted $g n t R$ gene $X O 00783$ that positively regulates the expression of $h r p G$ from $X$. oryzae pv. oryzae in minimal medium and in host plant. Interestingly, a mutation in this gene did not affect the virulence and growth of the pathogen in the host plant. A comparison of amino acid sequences revealed that its coding product showed significant homology $(90 \%$ identity) with the predicted $X$. campestris pv. campestris GntR member XC_3561 but not HpaR1. As shown in the results presented here, a mutation in XC_3561 did not influence HR and virulence induction. To further verify whether or not this putative GntR affects hrpG expression in $X$. campestris pv. campestris, we introduced the $h r p G$ promoter-gusA reporter plasmid pGUShrpG into the mutant strain $3561 \mathrm{pk}$ of the ORF $X C \_3561$ and assayed its GUS activity. The result showed that it produced similar GUS activity with the strain 8004/ pGUShrpG in MMX medium (data not shown). This suggests that XC_3561 may not have an effect on the expression of hrpG in $X$. campestris pv. campestris.

Our work has revealed a very complex mechanism for the transcriptional regulation of $h p a R l$ and $h r p G$ genes in different environments. The reporter strain 2736nk/pGUS2736 produced significantly higher GUS activity than the strain 8004/ pGUS2736 in standard media; however, 2736nk/pGUS2736 did not produce distinct GUS activity in the host plant, whereas 8004/pGUS2736 did. Based on these data and the fact that HpaR1 can autorepress its own expression, we propose the following mode for hpaRl expression regulation. When the bacterial cells grow in a host plant, a plant-specific factor induces the expression of a bacterial protein (regulator A) that can suppress hpaRl expression. However, regulator A can be inactivated by HpaR1, so that the hpaRl gene can be expressed in the wild-type cells but not in the HpaR1-deficient mutant cells. In media, hpaRl can be expressed without HpaR1 for lack of the plant factor, and the hpaRl expression in the wild-type cells is significantly weaker than in the HpaR1-deficient mutant cells because of the feedback inhibition of HpaR1. The results from promoter-gusA reporter analysis reveal that HpaR1 can positively and negatively affect the expression of $h r p G$ in host plant and media, respectively. In host plants, the effect may be through the hypothetical regulator A, which can negatively influence the expression of $h r p G$ directly or indirectly. In media, there is probably a factor that differs from the plant factor. This factor can induce the expression of another protein (regulator B), which positively regulates the expression of $h r p G$ either directly or indirectly, but its own expression is negatively controlled by HpaR1. Further studies to verify this proposed model, such as identification of the signal factors and the induced regulator proteins from media and host plants, will facilitate our understanding of the hrp regulation mechanism of $X$. campestris pv. campestris.

\section{MATERIALS AND METHODS}

\section{Bacterial strains, plasmids, and growth conditions.}

The bacterial strains and plasmids used in this study are listed in Table 1. E. coli strains were grown in Luria-Bertani medium (Miller 1972) at $37^{\circ} \mathrm{C}$. X. campestris pv. campestris strains were grown at $28^{\circ} \mathrm{C}$ in NYG medium ( $5 \mathrm{~g}$ of peptone, 3 $\mathrm{g}$ of yeast extract, and $20 \mathrm{~g}$ of glycerol per liter) (Daniels et al. 1984b), NY medium (NYG medium but without glycerol), and the minimal medium MMX $\left(2.0 \mathrm{~g}\right.$ of $\left[\mathrm{NH}_{4}\right]_{2} \mathrm{SO}_{4}, 4.0 \mathrm{~g}$ of $\mathrm{K}_{2} \mathrm{HPO}_{4}, 6.0 \mathrm{~g}$ of $\mathrm{KH}_{2} \mathrm{PO}_{4}, 0.2 \mathrm{~g}$ of $\mathrm{MgSO}_{4} \cdot 7 \mathrm{H}_{2} \mathrm{O}, 1.0 \mathrm{~g}$ of citric acid, and $5.0 \mathrm{~g}$ of glucose per liter) (Daniels et al. 1984a). Antibiotics were added at the following concentrations as required: Kan at $25 \mu \mathrm{g} \mathrm{ml}^{-1}$; Rif at $50 \mu \mathrm{g} \mathrm{ml}{ }^{-1}$; ampicillin at
$100 \mu \mathrm{g} \mathrm{ml}^{-1}$; spectinomycin at $50 \mu \mathrm{g} \mathrm{m}^{-1}$; and Tet at $5 \mu \mathrm{g} \mathrm{ml}^{-1}$ for $X$. campestris pv. campestris and $15 \mu \mathrm{g} \mathrm{ml}^{-1}$ for E. coli.

\section{DNA and RNA manipulations.}

DNA manipulations followed the procedures described by Sambrook and associates (1989). Conjugation between X. campestris pv. campestris and E. coli strains was performed as described by Turner and associates (1985). The restriction endonucleases, T4 DNA ligase, and $p f u$ polymerase were provided by Promega (Shanghai, China). The total RNAs were extracted from the cultures of the $X$. campestris pv. campestris strains with a total-RNA extraction kit (Promega) and the RT was performed using a cDNA synthesis kit (Fermentas Co., Vilnius, Lithuania). Each kit was used according to the manufacturer's instructions.

To investigate the composition of $X C \_2736$ operon and the effect of $X C \_2736$ mutation, RT-PCR was employed. The synthesized cDNAs from the extracted total RNAs of the wildtype strain 8004 , the $X C \_2736$ nonpolar mutant 2736nk, and polar mutant $2736 \mathrm{pk}$ were used as templates to amplify the sequences spanning two different genes within the cluster $X C \_2737$ to $X C \_2741$ or the internal sequences of the $X C \_2737$ to $X C \_2741$ ORF with the corresponding primer sets. Simultaneously, PCR with the total DNA or total RNA without the addition of reverse transcriptase was performed as a positive or negative control.

To assay the transcription level of $h r p G$ and $h r p X$, a realtime quantitative PCR was carried out, as previously described (Lu et al. 2009). Real-time quantitative PCR was conducted with total RNA extracted from the wild-type strain 8004 and the XC_2736 mutant strain 2736nk. SYBR green-labeled PCR fragments were amplified by using primer sets hrpGF/R and hrpXF/R, designed from the transcribed region of the $h r p G$ and $h r p X$ gene, respectively. The expression level of the $16 \mathrm{~S}$ rRNA gene was used as an internal standard. All real-time PCR tests were performed in triplicate.

\section{Construction of insertional mutants and complementation.}

Insertional mutants of the target genes were constructed using the suicide plasmid pK18mob (Table 1), as previously described (Lu et al. 2007). A 300- to 500-bp internal fragment of the target ORF was amplified by PCR using the corresponding primers and cloned into suicide plasmid pK18mob in the same orientation as the lac $Z$ promoter to guarantee the construction of nonpolar mutants. The resulting recombinant plasmid was introduced from the E. coli JM109 (Table 1) into the $X$. campestris pv. campestris wild-type strain 8004 by triparental conjugation using pRK2073 (Table 1) as the helper plasmid. To construct polar mutants, the amplified DNA fragments were cloned into the SmaI site of suicide plasmid $\mathrm{pK} 18 m o b$ in the opposite orientation to the lacZ promoter. Mutants were confirmed by PCR as previously described.

For complementation of the XC_2736 mutant, an 863-bp DNA fragment containing the $X C_{\_} 2736$ coding region and extending from $412 \mathrm{bp}$ upstream of the $5^{\prime}$ end to $91 \mathrm{bp}$ downstream of the $3^{\prime}$ end of the ORF was amplified using the primers $\mathrm{C} 2736 \mathrm{~F} / \mathrm{R}$, and the amplified DNA fragment was cloned into the plasmid pLAFR3 (Table 1) to generate the recombinant plasmid pL2736 (Table 1). The recombinant plasmid was transferred into the $X C \_2736$ mutant by triparental conjugation, resulting in strain $\mathrm{C} 2736$ (Table 1).

\section{Determination of transcriptional start site.}

5'-RACE was used to determine the transcriptional start site of the gene XC_2736. Total cellular RNA was extracted and treated with RNase-free DNase I (Qiagen, Hilden, Germany), followed by a second purification. cDNA fragments were ob- 
tained using the 5'-RACE kit (Invitrogen Life Technologies, San Diego, CA, U.S.A.). RNA was reverse transcribed using the XC_2736 sequence-specific primer RTP1. An anchor sequence was then added to the $3^{\prime}$ end of the cDNA using terminal deoxynucleotide transferase, followed by direct amplification of tailed cDNA using the nested gene-specific primers RTP2 and RTP3 and the anchor-specific primer provided. PCR products were then cloned into the pMD19-T vector and sequenced.

\section{Electrophoretic mobility shift assays.}

For overproduction of the product of $X C_{-} 2736$, the ORF was amplified by PCR from the genomic DNA of strain 8004 using primers $\mathrm{O} 2736 \mathrm{~F} / \mathrm{R}$. Primers were modified to give BamHI- or HindIII-compatible ends. After being confirmed by sequencing, the amplified DNA fragment was cloned into the expression vector $\mathrm{pQE}-30$ (Qiagen) to generate the recombinant plasmid pQE-30-2736. In this plasmid, $X C \_2736$ is fused $\mathrm{N}$-terminally in frame to the $\mathrm{His}_{6}$-tag coding region of the plasmid pQE-30. The recombinant plasmid pQE-30-2736 was transformed into E. coli JM109, resulting in strain JM109/pQE30-2736. For overproduction and purification of the fused protein, the strain JM109/pQE-30-2736 was grown to an optical density at $600 \mathrm{~nm}\left(\mathrm{OD}_{600}\right)$ of 0.6 , and then induced by addition of $1.0 \mathrm{mM}$ IPTG. After the culture was grown for a further $4 \mathrm{~h}$, the fused protein was purified by Ni-NTA resin (Qiagen). The purified protein $\mathrm{His}_{6}-\mathrm{HpaR} 1$ or crude cell extract was mixed with a 470-bp DNA fragment which was amplified by PCR using primers P2736F and P2736R, containing the putative $X C \_2736$ promoter region. A control fragment was amplified from the coding sequence of $X C \_2736$ by using primers $2736 \mathrm{~F}$ and $2736 \mathrm{R}$. Fragments were labeled using $[\gamma-$ $\left.{ }^{32} \mathrm{P}\right] \mathrm{dATP}$ and T4 polynucleotide kinase. The labeled DNA fragment $(1 \mathrm{ng})$ was incubated with cell extracts or purified protein for $20 \mathrm{~min}$ at $30^{\circ} \mathrm{C}$ in $20 \mu \mathrm{l}$ (total volume) of binding buffer (20 mM Tris- $\mathrm{HCl}, 10 \mathrm{mM} \mathrm{NaCl}, 1 \mathrm{mM}$ EDTA, and 1 $\mathrm{mM}$ dithiothreitol, $\mathrm{pH}$ 8.0) containing $1 \mu \mathrm{g}$ of sonicated salmon sperm DNA and $3 \mu \mathrm{g}$ of bovine serum albumin. Samples were loaded onto a $6 \%$ polyacrylamide-Tris-borateEDTA gel, and visualized by autoradiography.

\section{In vitro transcription assays.}

In vitro transcription assays on the promoter DNA of $X C \_2736$ were performed using the experimental procedure modified from Friedman and O'Brian (2004). The promoter DNA fragment was generated by PCR amplification using the total DNA of the wild-type strain 8004 as template and primers 2641ivtF and 2641ivtR. The fragment includes the promoter region as well as 195-bp coding region downstream of the annotated translation start site of the gene (Qian et al. 2005). To remove imidazole, $\mathrm{His}_{6}$-HpaR1 was dialyzed against 200 volumes of Tris- $\mathrm{HCl}$ buffer $(10 \mathrm{mM}$ Tris- $\mathrm{HCl}$ [pH 8.0] and $1 \mathrm{mM}$ dithiothreitol [DTT]) at $4{ }^{\circ} \mathrm{C}$. For in vitro transcription, $\mathrm{His}_{6}$ HpaR1 was incubated for $30 \mathrm{~min}$ at room temperature in transcription buffer (40 mM Tris- $\mathrm{HCl}[\mathrm{pH} 7.9], 6 \mathrm{mM} \mathrm{MgCl}, 2$ $\mathrm{mM}$ spermidine, $10 \mathrm{mM} \mathrm{NaCl}, 5 \mathrm{mM}$ DTT, $5 \%$ glycerol, 50 $\mathrm{mM} \mathrm{KCl}$, and $1 \mathrm{U}$ of RNase inhibitor) containing $4 \mathrm{nM}$ promoter template DNA. Then, a NTP mixture $(250 \mu \mathrm{M}$ each ATP, CTP, and GTP; $20 \mu \mathrm{M} \mathrm{UTP;} \mathrm{and} 8 \mu \mathrm{M}\left[\alpha{ }^{-32} \mathrm{P}\right] \mathrm{UTP}$ [3,000 Ci/mmol, $10 \mathrm{mCi} / \mathrm{ml}])$ and $1 \mathrm{U}$ of $E$. coli RNA polymerase Holoenzyme (sigma saturated) (Epicentre, Madison, WI, U.S.A.) was added to start the transcription. After incubation at $28^{\circ} \mathrm{C}$ for $30 \mathrm{~min}$, reactions were terminated by addition of one volume of $2 \times$ Loading Dye Solution (Fermentas Co.) and chilled on ice. After incubation at $70^{\circ} \mathrm{C}$ for $10 \mathrm{~min}$, transcription products were run on a $5 \%$ polyacrylamide gel containing $7 \mathrm{M}$ urea in $1 \times$ Tris-borate-EDTA electrophoresis buffer. The transcripts obtained were analyzed by a phosphorimager screen (Typhoon 9410; Amersham Biosciences, Piscataway, NJ, U.S.A.).

\section{GUS activity assays.}

GUS activities were determined by using $\rho$-nitrophenyl- $\beta$-Dglucuronide as a substrate, as described by Henderson and associates (1985), after growth of the $X$. campestris pv. campestris strains in medium for a period of time. Histochemical GUS staining was performed by using 5-bromo-4-chloro-3-indolylglucuronide (Promega Corp., Madison, WI) as a substrate, essentially as described by Jefferson and associates (1987), after $X$. campestris pv. campestris strains were introduced into host plant leaves. For GUS activity quantification of bacterial cells in plant leaves, the fluorogenic substrate 4-methylumbelliferyl$\beta$-D-glucuronide was used following the method developed by Vojnov and associates (2001).

\section{Plant assay and determination of the growth of bacteria in planta.}

The virulence of $X$. campestris pv. campestris to Chinese radish (Raphanus sativus) was tested by the leaf-clipping method (Dow et al. 2003). Leaves were cut with scissors dipped in the bacterial suspensions of an $\mathrm{OD}_{600}$ of 0.1 . Lesion length was measured 10 days after inoculation, and data were analyzed by $t$ test.

The growth of bacteria in radish leaf tissues was determined as previously described (Lu et al. 2007). To assess the stability of the recombinant plasmid in the $X$. campestris pv. campestris strains in planta, plant leaves inoculated with $X$. campestris $\mathrm{pv}$. campestris strains were homogenized, diluted in sterile water, and plated on NYG agar plates supplemented with Rif only. The colonies formed on the plates were then replicated onto NYG agar plates supplemented with Rif and Tet, and the colonies on the two kinds of plates were calculated and compared.

The HR was tested on the pepper plant ECW-10R (Capsicum annuum cv. ECW-10R). The pepper leaves were inoculated by infiltrating an approximately 5 - $\mu$ l bacterial suspension $\left(1 \times 10^{7} \mathrm{CFU} / \mathrm{ml}\right)$ in $10 \mathrm{mM}$ sodium phosphate buffer $(5.8 \mathrm{mM}$ $\mathrm{Na}_{2} \mathrm{HPO}_{4}$ and $4.2 \mathrm{mM} \mathrm{NaH} \mathrm{PO}_{4}, \mathrm{pH}$ 7.0) into the abaxial leaf surface by using a blunt-end plastic syringe. The inoculated plants were maintained in a greenhouse with a 12-h cycle of day and night illuminations with a fluorescent lamp and a constant temperature of $28^{\circ} \mathrm{C}$, and the $\mathrm{HR}$ symptoms were observed and photographed. For the electrolyte leakage assays, measurements were carried out as described by Castañeda and associates (2005). For each sample, four $0.4-\mathrm{cm}^{2}$ leaf disks were collected from the bacteria-infiltrated area and incubated in $5 \mathrm{ml}$ of distilled water. Conductivity was measured with a DDS-307A conductometer. Three samples were taken for each measurement in each experiment.

GntR-like members selection, multiple sequence alignments, and phylogenetic tree construction.

Apart from proteins annotated as GntR-like regulators, other putative GntR from X. campestris pv. campestris proteome were checked using GntR Pfam profile (Eddy 1998). The secondary structural features of all the predicted GntR members were analyzed using PSI-pred, NetSurfP, and Jpred automated prediction programs on the PredictProtein server (Pabo and Sauer 1992). A consensus of all the secondary structure predictions was considered for better validity. Multiple alignments were developed with the MULTIALIN (Corpet 1988) and CLUSTALW (Thompson et al. 1994) programs. Distances between aligned proteins were computed with the PROTDIST program using the Dayhoff PAM matrix (Young et al. 1979). The program estimated phylogenies from distances in the ma- 
trix data using the Fitch-Margoliash algorithm (Fitch and Margoliash 1967). The phylogenetic tree was drawn using the TREEVIEW.

\section{ACKNOWLEDGMENTS}

This work was supported by The National Natural Science Foundation of China (30730004 and 30771177) and the Plans for Construction of Scientific Topnotch and Innovation Team in Guangxi University.

\section{LITERATURE CITED}

Alfano, J. R., and Collmer, A. 2004. Type III secretion system effector proteins: Double agents in bacterial disease and plant defense. Annu. Rev. Phytopathol. 42:385-414.

Alvarez, A. M. 2000. Black rot of crucifers. Pages 21-52 in: Mechanisms of Resistance to Plant Diseases. A. J. Slusarenko, R. S. S. Fraser, and L. C. van Loon, eds. Kluwer Academic Publishers, Dordrecht, The Netherlands.

Arlat, M., Gough, C. L., Barber, C. E., Boucher, C., and Daniels, M. J 1991. Xanthomonas campestris contains a cluster of hrp genes related to the larger hrp cluster of Pseudomonas solanacearum. Mol. Plant-Microbe Interact. 4:593-601.

Casali, N., White, A. M., and Riley, L. W. 2006. Regulation of the Mycobacterium tuberculosis mce1 operon. J. Bacteriol. 188:441-449.

Castañeda, A., Reddy, J. D., El-Yacoubi, B., and Gabriel, D. W. 2005. Mutagenesis of all eight avr genes in Xanthomonas campestris pv. campestris had no detected effect on pathogenicity, but one avr gene affected race specificity. Mol. Plant-Microbe Interact. 18:1306-1317.

Cornelis, G. R., and Van Gijsegem, F. 2000. Assembly and function of type III secretion systems. Annu. Rev. Microbiol. 54:735-774.

Corpet, F. 1988. Multiple sequence alignment with hierarchical clustering. Nucleic Acids Res. 16:10881-10890.

Daniels, M. J., Barber, C. E., Turner, P. C., Cleary, W. G., and Sawczyc, M. K. 1984a. Isolation of mutants of Xanthomonas campestris pathovar campestris showing altered pathogenicity. J. Gen. Microbiol. 130:24472455.

Daniels, M. J., Barber, C. E., Turner, P. C., Sawczyc, M. K., Byrde, R. J W., and Fielding, A. H. 1984b. Cloning of genes involved in pathogenicity of Xanthomonas campestris pv. campestris using the broad host range cosmid pLAFR1. EMBO (Eur. Mol. Biol. Organ.) J. 3:33233328

da Silva, A. C., Ferro, J. A., Reinach, F. C., Farah, C. S., Furlan, L. R., Quaggio, R. B., Monteiro-Vitorello, C. B., Sluys, M. A., Almeida, N. F., Alves, L. M., Do Amaral, A. M., Bertolini, M. C., Camargo, L. E., Camarotte, G., Cannavan, F., Cardozo, J., Chambergo, F., Ciapina, L. P., Cicarelli, R. M., Coutinho, L. L., Cursino-Santos, J. R., El-Dorry, H., Faria, J. B., Ferreira, A. J., Ferreira, R. C., Ferro, M. I., Formighieri, E. F., Franco, M. C., Greggio, C. C., Gruber, A., Katsuyama, A. M., Kishi, L. T., Leite, R. P., Lemos, E. G., Lemos, M. V., Locali, E. C., Machado, M. A., Madeira, A. M., Martinez-Rossi, N. M., Martins, E. C., Meidanis, J., Menck, C. F., Miyaki, C. Y., Moon, D. H., Moreira, L. M., Novo, M. T., Okura, V. K., Oliveira, M. C., Oliveira, V. R., Pereira, H. A., Rossi, A., Sena, J. A., Silva, C., De Souza, R. F., Spinola, L. A., Takita, M. A., Tamura, R. E., Teixeira, E. C., Tezza, R. I., Trindade Dos Santos, M., Truffi, D., Tsai, S. M., White, F. F. Setubal, J. C., and Kitajima, J. P. 2002. Comparison of the genomes of two Xanthomonas pathogens with differing host specificities. Nature 417:459-463.

Dow, M. 2008. Diversification of the function of cell-to-cell signaling in regulation of virulence within plant pathogenic Xanthomonads. Sci. Signal. 1:pe23.

Dow, J. M., Crossman, L., Findlay, K., He, Y. Q., Feng, J. X., and Tang, J. L. 2003. Biofilm dispersal in Xanthomonas campestris is controlled by cell-cell signaling and is required for full virulence to plants. Proc. Natl. Acad. Sci. U.S.A. 100:10995-11000.

Eddy, S. R. 1998. Profile hidden Markov models. Bioinformatics 14:755763.

Fitch, W. M., and Margoliash, E. 1967. Construction of phylogenetic trees. Science 155:279-284

Friedman, Y. E., and O'Brian, M. R. 2004. The ferric uptake regulator (Fur) protein from Bradyrhizobium japonicum is an iron responsive transcriptional repressor in vitro. J. Biol. Chem. 279:32100-32105.

Fujita, Y., Fujita, T., Miwa, Y., Nihashi, J., and Aratani, Y. 1986. Organization and transcription of the gluconate operon, gnt, of Bacillus subtilis. J. Biol. Chem. 261:13744-13753.

Haine, V., Sinon, A., Van Steen, F., Rousseau, S., Dozot, M., Lestrate, P., Lambert, C., Letesson, J. J., and De Bolle, X. 2005. Systematic targeted mutagenesis of Brucella melitensis $16 \mathrm{M}$ reveals a major role for GntR regulators in the control of virulence. Infect Immun. 73:5578-5586.

Haydon, D. J., and Guest, J. R. 1991. A new family of bacterial regulatory proteins. FEMS (Fed. Eur. Microbiol. Soc.) Microbiol. Lett. 63:291 295

He, Y. Q., Zhang, L., Jiang, B. L., Zhang, Z. C., Xu, R. Q., Tang, D. J., Qin, J., Jiang, W., Zhang, X., Liao, J., Cao, J. R., Zhang, S. S., Wei, M. L., Liang, X. X., Lu, G. T., Feng, J. X., Chen, B. S., Cheng, J., and Tang, J. L. 2007. Comparative and functional genomics reveals genetic diversity and determinants of host specificity among reference strains and a large collection of Chinese isolates of the phytopathogen Xanthomonas campestris pv. campestris. Genome Biol. 8:R218.

Henderson, R. F., Benson, J. M., Hahn, F. F., Hobbs, C. H., Jones, R. K., Mauderly, J. L., McClellan, R. O., and Pickrell, J. A. 1985. New approaches for the evaluation of pulmonary toxicity: Bronchoalveolar lavage fluid analysis. Fundam. Appl. Toxicol. 5:451-458.

Hoskisson, P. A., and Rigali, S. 2009. Chapter 1: Variation in form and function the helix-turn-helix regulators of the GntR superfamily. Adv. Appl. Microbiol. 69:1-22

Huang, D. L., Tang, D. J., Liao, Q., Li, X. Q., He, Y. Q., Feng, J. X., Jiang, B. L., Lu, G. T., and Tang, J. L. 2009. The Zur of Xanthomonas cam pestris is involved in hypersensitive response and positively regulates the expression of the hrp cluster via $h r p X$ but not $h r p G$. Mol. Plant-Microbe Interact. 22:321-329.

Hueck C. J. 1998. Type III protein secretion systems in bacterial pathogens of animals and plants. Microbiol. Mol. Biol. Rev. 62:379-433.

Huynh, T. V., Dahlbeck, D., and Staskawicz, B. J. 1989. Bacterial blight of soybean: Regulation of a pathogen gene determining host cultivar specificity. Science 245:1374-1377.

Jefferson, R. A., Kavanagh, T. A., and Bevan, M. W. 1987. GUS fusions: Beta-glucuronidase as a sensitive and versatile gene fusion marker in higher plants. EMBO (Eur. Mol. Biol. Organ.) J. 6:3901-3907.

Jiang, B. L., He, Y. Q., Cen, W. J., Wei, H. Y., Jiang, G. F., Jiang, W. Hang, X. H., Feng, J. X., Lu, G. T., Tang, D. J., and Tang, J. L. 2008. The type III secretion effector XopXccN of Xanthomonas campestris pv. campestris is required for full virulence. Res. Microbiol. 159:216 220.

Jones, J. D., and Dangl, J. L. 2006. The plant immune system. Nature 444:323-329

Leong, S. A., Ditta, G. S., and Helinski, D. R. 1982. Heme biosynthesis in Rhizobium. Identification of a cloned gene coding for delta-aminolevulinic acid synthetase from Rhizobium meliloti. J. Biol. Chem. 257:87248730

Lindgren, P. B. 1997. The role of hrp genes during plant-bacterial interactions. Annu. Rev. Phytopathol. 35:129-152.

Lu, G. T., Ma, Z. F., Hu, J. R., Tang, D. J., He, Y. Q., Feng, J. X., and Tang, J. L. 2007. A novel locus involved in extracellular polysaccharide production and virulence of Xanthomonas campestris pathovar campestris. Microbiology 153:737-746.

Lu, G. T., Xie, J. R., Chen, L., Hu, J. R., An, S. Q., Su, H. Z., Feng, J. X., He, Y. Q., Jiang, B. L., Tang, D. J., and Tang, J. L. 2009. Glyceraldehyde-3-phosphate dehydrogenase of Xanthomonas campestris pv. campestris is required for extracellular polysaccharide production and full virulence. Microbiology 155:1602-1612.

Miller, J. H. 1972. Experiments in Molecular Genetics. Cold Spring Harbor Laboratory Press, Cold Spring Harbor, NY, U.S.A.

Mole, B. M., Baltrus, D. A., Dangl, J. L., and Grant, S. R. 2007. Global virulence regulation networks in phytopathogenic bacteria. Trends $\mathrm{Mi}$ crobiol. 15:363-371.

Newman, M. A., von Roepenack-Lahaye, E., Parr, A., Daniels, M. J., and Dow, J. M. 2001. Induction of hydroxycinnamoyl-tyramine conjugates in pepper by Xanthomonas campestris, a plant defense response activated by $h r p$ gene-dependent and $h r p$ gene-independent mechanisms. Mol. Plant-Microbe Interact. 14:785-792.

Pabo, C. O., and Sauer, R. T. 1992. Transcription factors: Structural families and principles of DNA recognition. Annu. Rev. Biochem. 61:10531095

Qian, W., Jia, Y., Ren, S. X., He, Y. Q., Feng, J. X., Lu, L. F., Sun, Q., Ying, G., Tang, D. J., Tang, H., Wu, W., Hao, P., Wang, L., Jiang, B. L., Zeng, S., Gu, W. Y., Lu, G, Rong, L., Tian, Y., Yao, Z., Fu, G., Chen, B., Fang, R., Qiang, B., Chen, Z., Zhao, G. P., Tang, J. L., and $\mathrm{He}, \mathrm{C} .2005$. Comparative and functional genomic analyses of the pathogenicity of phytopathogen Xanthomonas campestris pv. campestris. Genome Res. 15:757-767.

Rigali, S., Derouaux, A., Giannotta, F., and Dusart, J. 2002. Subdivision of the helix-turn-helix GntR family of bacterial regulators in the FadR, HutC, MocR, and YtrA subfamilies. J. Biol. Chem. 277:12507-12515.

Sambrook, J., Fritsch, E. F., and Maniatis, T. 1989. Molecular Cloning: A Laboratory Manual, 2nd ed. Cold Spring Harbor Laboratory, Cold Spring Harbor, NY, U.S.A. 
Schäfer, A., Tauch, A., Jäger, W., Kalinowski, J., Thierbach, G., and Pühler, A. 1994. Small mobilizable multi-purpose cloning vectors derived from the Escherichia coli plasmids pK18 and pK19: Selection of defined deletions in the chromosome of Corynebacterium glutamicum. Gene 145:69-73.

Staskawicz, B., Dahlbeck, D., Keen, N., and Napoli, C. 1987. Molecular characterization of cloned avirulence genes from race 0 and race 1 of Pseudomonas syringae pv. glycinea. J. Bacteriol. 169:5789-5794.

Thompson, J. D., Higgins, D. G., and Gibson, T. J. 1994. CLUSTAL W: Improving the sensitivity of progressive multiple sequence alignment through sequence weighting, position-specific gap penalties and weight matrix choice. Nucleic Acids Res. 22:4673-4680.

Tsuge, S., Nakayama, T., Terashima, S., Ochiai, H., Furutani, A., Oku, T. Tsuno, K., Kubo, Y., and Kaku, H. 2006. Gene involved in transcriptional activation of the hrp regulatory gene hrpG in Xanthomonas oryzae pv. oryzae. J. Bacteriol. 188:4158-4162.

Turner, P., Barber, C. E., and Daniels, M. J. 1985. Evidence for clustered pathogenicity genes in Xanthomonas campestris pv. campestris. Mol. Gen. Genet. 199:338-343.

Vindal, V., Suma, K., and Ranjan, A. 2007. GntR family of regulators in Mycobacterium smegmatis: A sequence and structure based characterization. BMC Genomics 8:289.

Vojnov, A. A., Slater, H., Daniels, M. J., and Dow, J. M. 2001. Expression of the gum operon directing xanthan biosynthesis in Xanthomonas campestris and its regulation in planta. Mol. Plant-Microbe Interact. 14:768-774.
Vorhölter F. J., Schneiker, S., Goesmann, A., Krause, L., Bekel, T. Kaiser, O., Linke, B., Patschkowski, T., Rückert, C., Schmid, J., Sidhu, V. K., Sieber, V., Tauch, A., Watt, S. A., Weisshaar, B., Becker, A., Niehaus, K., and Pühler, A. 2008. The genome of Xanthomonas campestris pv. campestris B100 and its use for the reconstruction of metabolic pathways involved in xanthan biosynthesis. J. Biotechnol. 134:33-45.

Wei, K., Tang, D. J., He, Y. Q., Feng, J. X., Jiang, B. L., Lu, G. T., Chen, B., and Tang, J. L. 2007. hpaR, a putative marR family transcriptional regulator, is positively controlled by $\operatorname{HrpG}$ and $\operatorname{HrpX}$ and involved in the pathogenesis, hypersensitive response, and extracellular protease production of Xanthomonas campestris pathovar campestris. J. Bacteriol. 189:2055-2062.

Windgassen, M., Urban, A., and Jaeger, K. E. 2000. Rapid gene inactivation in Pseudomonas aeruginosa. FEMS (Fed. Eur. Microbiol. Soc.) Microbiol. Lett. 193:201-205.

Yanisch-Perron, C., Vieira, J., and Messing, J. 1985. Improved M13 phage cloning vectors and host strains: Nucleotide sequences of the M13mp18 and pUC19 vectors. Gene 33:103-119.

Yoshida, K., Fujita, Y., and Ehrlich, S. D. 2000. An operon for a putative ATP-binding cassette transport system involved in acetoin utilization of Bacillus subtilis. J. Bacteriol. 182:5454-5461.

Young, C. L., Barker, W. C., Tomaselli, C. M., and Dayhoff, M. O. 1979 Pages 73-93 in: Atlas of Protein Sequence and Structure. Volume 5 (Suppl. 3). M. O. Dayhoff, ed. National Biochemical Foundation, Silver Spring, MD, U.S.A. 